\title{
Inleiding in die teologiese arbeid van Walter Schmithals ${ }^{1}$
}

\author{
PB BOSHOFF
}

Walter Schmithals, professor in Nuwe Testament aan die KIRCHLICHE HOCHSCHULE BERLIN, stel homself aan studente voor as iemand wat uit piëtistiese kringe kom en 'n leerling van Bultmann. Die Piëtisme dring daarop aan dat geloof ERVAAR sal word; God se heil word deur die menslike aanvaarding afgerond; God wil dat die mens eksistensieel op sy hulp aanspraak maak. In die voorwoord tot "Die theologische Anthropologie des Paulus" stel Schmithals dat Paulus nie 'n leer oor God voordra nie, maar dat hy die mens, wat as sondaar en gelowige voor God staan, beskryf. Dit gaan om hierdie antropologie wat telkens weer gaan haal moet word soos Augustinus, Luther, Kierkegaard en Bultmann dit elkeen op sy manier gedoen het. Schmithals bly ook deurgaans bewus van die gevaar van Subjektivisme en lê klem daarop dat die heil van anderkant die menslike moontlikhede kom; dit bly GOD se heil wat aan ons GESKENK word in die verkondiging van sy Woord; dit gaan om TEOLOGIESE antropologie.

Schmithals kan beskou word as 'n kenner van die negentiendeeeuse Duitse teologie. Hy verwys dikwels na vraagstukke en standpunte wat van lankal bestaan en 'n uitspraak soos "ons kan maar in gedagte hou dat ons nie die eerstes is wat hierdie teks lees nie" is tipies van sy benadering. Dit is verder van belang dat Schmithals sy werk in noue arbeidsgemeenskap met die Ou-Testamentikus AHJ Gunneweg doen. Ek het betroubaar verneem dat die "wir" in die opstel "Barth, Bultmann und wir", wat al in 1969 verskyn het, uit Schmithals en Gunneweg bestaan. Om direkte spore van hierdie vriendskap in Schmithals se werk aan te toon is vir my nie moontlik nie. Die naaste aan die waarheid sou seker wees om te sê dat die geheel daarsonder anders sou gewees het.

Die bedoeling van hierdie artikel is nie om Schmithals teen een of ander agtergrond te verklaar nie of om hom te kritiseer nie, maar om hom voor te stel, 'n inleiding in sy denke te gee en 'n aansporing om sy eie geskrifte te lees. Die beste manier om dit te doen is dat ek as gids in die werkwinkel van hierdie groot teoloog optree. In ons 
bedryf het ons die voordeel dat die rou materiaal nie verdwyn as daarvan 'n produk gemaak is nie. Alles bly oor sodat iemand anders kan oordeel of jy die materiaal reg benut het, of jy dalk te veel daarmee wou uitrig, of jy dalk te min daarvan gemaak het. Schmithals se werkwinkel kan in twee afdelings onderskei word: die afronding van produkte of dogmatiese afdeling en die bewerking van rou materiaal of eksegetiese afdeling. Hoewel ons hierdie twee afdelings onderskei moet ons onthou dat die grens tussen bewerking en afronding soms baie dun is, dit bly immers EEN werkwinkel. Ter wille van die besoekers begin die gids by die afronding van produkte, die meer dogmatiese afdeling en ons vorder tot by die bewerking van rou materiaal, die meer eksegetiese afdeling. Teen die einde behoort ons ' $n$ geheelbeeld te kan vorm van Schmithals se werk.

\section{JESUS CHRISTUS}

Bultmann het 'n probleem aan sy teologiese nageslag agtergelaat wat nie maklik opgelos sou word nie. Dit het daarin bestaan dat Paulus en Johannes se ongeïnteresseerdheid in die "historiese Jesus" nie te rym is met die "historiese" Jesus-oorlewering van onkērugmatiese inslag wat die grondslag van die Sinoptiese Tradisie vorm nie. Bultmann bied ook nie 'n teologiese uitleg van die Sinoptiese Tradisie nie. Schmithals vertel dat hy Bultmann dikwels hieroor uitgevra het sonder om enige duidelikheid te $\mathrm{kry}^{2}$. Met sy intreerede op 9.5.1962 as dosent in Marburg "Paulus und der 'historische' Jesus" aanvaar Schmithals die worsteling met hierdie probleem as sy lewenstaak. Onder "historiese Jesus" verstaan Schmithals nie die DAT van Jesus se historiese bestaan, sy geboorte, menswees, lyding en sterwe nie, maar die HOE en WAT van sy lewe.

Paulus vertel nie van Jesus se leer of lewenshouding nie. Dat $\mathrm{Hy}$ mens was en aan die kruis gesterf het hoort tot die DAT van sy historiese bestaan. Schmithals stel vas dat dit nie net Paulus is wat nie in die HOE en WAT belang stel nie, ook die res van die Nuwe Testament behalwe die Sinoptiese Evangelies. Eers Justinus het die Jesus-oorlewering weer 'n plek gegee. Maar selfs tussen Justinus en Irenaeus het baie Christelike literatuur nie hieraan aandag gegee nie ${ }^{5}$. In vergelyking met hierdie fundamentele kerklike tradisie het die evangelies met hul "historiese" Jesus-tradisie tot in die helfte van die tweede eeu apokrief in die sin van verborge gebly'. 
Dat die probleem daarmee nog lank nie opgelos is nie, is duidelik. Groter helderheid kom wanneer ons Schmithals se uitleg van die historiese Jesus, Bybelse of kërugmatiese Jesus, aardse Jesus en dogmatiese Jesus volg?.

Die HISTORIESE JESUS kom na vore waar mense deur middel van historiese navorsing probeer om uit die Nuwe Testament en ander bronne ' $n$ beeld van die aardse Jesus, sy lewe, sy boodskap, sy gedrag, sy geloof, sy persoonlikheid te vorm.

Die KËRUGMATIESE JESUS is Jesus volgens die Bybelse belydenis as die Christus. Jesus Christus die opgestane en verkondigde Heer.

Die historiese wetenskap maak daarop aanspraak dat hulle verby die beeld wat die gemeente van gelowiges rondom Jesus gebou het, deurgedring het tot die werklike AARDSE JESUS.

Die belydenis maak ook daarop aanspraak dat die KĒRUGMATIESE JESUS dieselfde werklike AARDSE JESUS is soos Hy Hom aan die oog van die geloof toon. Die belydenis gryp terug na Jesus se menswording en kruisdood. Die historiese wetenskap is nie tevrede met hierdie skrale gegewens nie, maar maak veel van die werke van Jesus soos dit in die Sinoptiese Evangelies beskryf word.

Sowel die HISTORIESE JESUS as die KËRUGMATIESE JESUS is 'n DOGMATIESE JESUS. Dat die KERUGMATIESE JESUS 'n dogmatiese weergawe van die AARDSE JESUS is, word nêrens betwyfel nie. Schmithals voeg egter by dat die HISTORIESE JESUS nooit bedoel was om die historiese nuuskierigheid te bevredig nie, hy wou steeds die inhoud van geloof bepaal. Hy wil die BYBELSE JESUS vervang. Al die HISTORIESE JESUSSE is dogmatiese gestaltes: "der konsequent eschatologische Jesus; die absolute Persönlichkeit Jesus; der Sozialrevolutionër Jesus; der mitmenschliche Jesus; der aufgeklärte Jesus, der fromme Rebell Jesus - was anders stellen diese Jesusgestalten dar als dogmatische Gegebenheiten" Die HISTORIESE JESUS, in al sy vorme, is vervangbaar. Omdat hy die heil nog nie gebring het nie, moet sy werk deur mense voortgesit word, kom menslike werk weer in die plek van God se genade ${ }^{9}$.

Wat die AARDSE JESUS betref is Schmithals oortuig dat hy 'n apokaliptikus was. Hy voer die volgende argumente aan ${ }^{10}$ :

1. Jesus het uitgegaan van die boodskap van Johannes die Doper wat apokalipties bepaald was. Johannes het die mense tot inkeer geroep omdat die wêreldoordeel naby is. 
2. Jesus se werke het uitgeloop op die belydenis van sy opstanding. Die belydenis van die opstanding is ' $n$ sentrale apokaliptiese uitspraak. Die belydenis van Jesus "as eersteling uit dié wat gesterf het" (1 Kor 15:20) pas hierby in.

3. Jesus is deur die Romeine gekruisig. Dit is die dood van 'n politieke misdadiger. Dit gee telkens aanleiding om hom as politieke rebel te sien. Hierdie siening word deur die pasifistiese houding van die oudste gemeente weerlê. Schmithals meen dat Jesus as apokaliptikus verwag het dat die Ryk van God gaan aanbreek en dat dit 'n einde aan alle wêreldlike magte sou maak. Die Romeine het maar sleg tussen die zelotiese hoop op die Seun van Dawid en die apokaliptiese verwagting van die komende Godsryk onderskei.

4. In AL die tradisielae van die Nuwe Testament speel die Gees 'n belangrike rol. Die geestesbegaafdheid is deurgaans in die OerChristendom met die Ou-Testamentiese eindtydsbeloftes in verband gebring en verstaan. Die apokaliptiese oorsprong van hierdie wydverspreide tradisie kan moeilik ontken word.

Wat is die verhouding tussen die HISTORIESE JESUS en die KERUGMATIESE JESUS? Schmithals beskryf dit met die uitdrukkings "Diskontinuität" en "Kontinuität" en met "Erwartung" en "Erfüllung"'11.

Die kontinuïteit bestaan daarin dat Jesus verwag het dat die Ryk van God sal aanbreek. Die diskontinuiteit bestaan daarin dat die kerk sedert Pase bely dat die tyd nou vervul is, God handel eens en vir altyd met ons deur hierdie selfde Jesus wat die Godsryk verwag het. Die kerk herhaal nie wat Jesus verkondig het nie, maar verkondig Homself. Die kerk glo nie wat Jesus geglo het nie, maar glo in Hom.

Schmithals verduidelik sy standpunt onder andere in sy Markuskommentaar waar hy die waterdoop van Johannes teenoor die doop met die Heilige Gees van Jesus stel. Johannes het in die woestyn 'n bekeringsdoop tot vergifnis van sondes verkondig: Soos wat Israel die sekerhede van Egipte laat vaar het en hulle aan die leiding van God in die woestyn toevertrou het, so roep Johannes die volk uit hul valse sekerhede, uit hul vertroue op dit waaroor hulle beskik. Hierdie oproep beteken bekering. Hierin is Johannes die voorloper van die Messias. So ' $n$ bekering is die noodwendige voorveronderstelling om die heil te ontvang. Maar hierdie "nulpunt" in die woestyn 
is nog nie die heil self nie. Johannes bring nog nie die heil self nie. Eers Jesus bring die volk tot in die beloofde land, Hy bring die eskatologiese heil, Hy doop met die Heilige Gees. Die heil in Christus is die beloofde en verwagte heil.

Schmithals se groot verdienste as teoloog lê in die feit dat hy 'n antwoord gekry het op die vraag waarom die Sinoptiese Evangelies dan anders as Paulus in die HOE en WAT van Jesus se lewe belangstel. Die antwoord lê daarin dat hierdie belangstelling net skyn is. Die "Grundschrift" wat ten grondslag van Markus lê en ook van Matteus en Lukas het nie 'n historiese belangstelling nie, maar is teologies geïnteresseerd. Die tema bly die Christusbelydenis van die gemeente na Pase. Die vorm waarin hierdie meesterteoloog sy stof aanbied is die van 'n vertelling. As hy vertel dat Jesus die volk GELEER het, sonder om van sy PREKE in te sluit, is die bedoeling dat die VERTELLINGS SELF Jesus se leer aanbied en dat $\mathrm{Hy}$, Jesus, die inhoud daarvan is. Veral by die wonderberigte kom die simboliese, metaforiese aard van die "Grundschrift" na vore ${ }^{12}$.

Hierdie ontdekking van die KËRUGMATIESE JESUS in die "Grundschrift" is Schmithals se blywende bydrae aan die Christelike teologie. Schmithals bly erfgenaam van Bultmann en hy oortref Bultmann selfs as hy vasstel dat die KERK NOOIT van die HISTORIESE JESUS vertel het nie: "KIRCHLICHE Überlieferung des sogenannten historischen Jesus hat es nie gegeben"13.

Daarmee is alle probleme nog nie opgelos nie. In die Sinoptiese Evangelies is daar Jesus-sêgoed geïdentifiseer waarin Jesus nie self die Messias is nie, maar self die Seun van die Mens verwag. Hierdie sêgoed veronderstel ook nie die paasgebeure nie. Schmithals soek die oorsprong van hierdie sêgoed by 'n Galilese Jesus-sekte, wat met die Ebioniete in verband gebring kan word. Hulle het nie aan die kerk behoort nie omdat hulle Jesus as 'n mens soos al die ander gesien het, sy opstanding het nog nie plaasgevind nie. Hulle het Jesus se sêgoed bewaar omdat hulle Hom as profeet beskou het. Volgens Schmithals het die evangelis Markus sommige van hierdie sêgoed in die grondskrif opgeneem om hierdie Jesus-mense vir die kerklike boodskap te wen deur aan te toon dat die "historiese" en "kērugmatiese" Jesus identies is. Na Markus is hierdie sêgoed vollediger versamel en teologies geredigeer waarna Matteus en Lukas dit ook gebruik het ${ }^{14}$. 


\section{APOKALIPTIEK}

Schmithals tipeer die apokaliptiese lewenshouding as 'n wyse waarop daar antwoord gegee word op die pessimisme wat mense in die aangesig van die ervaarde en ervaarbare werklikheid beetpak ${ }^{\mathbf{1 5}}$.

Apokaliptici beskou die uur waarin hulle leef as die laaste van die bose wêreld. Alles word nou beslis. Bekeer julle ${ }^{16}$ !

Die tydperk waarin ons nou lewe is die tyd van stryd en ongeregtigheid en die dood, dit staan onder heerskappy van God se teenstander, die Satan. Maar God het nog 'n tydperk gemaak waarin Hy alleen sal heers. Hierdie tydperk is aan die kom. Tussen die teenswoordige tyd en die toekomstige bestaan daar geen kontinuïteit nie. Oud en nuut staan teenoor mekaar. Vir hierdie wêreld het die apokaliptikus geen hoop nie, ook geen verantwoordelikheid nie, hy hoop op die nuwe skepping ${ }^{17}$. Deur aanhoudende gebed en smekinge vra hy dat God einde moet maak aan hierdie tyd ${ }^{\mathbf{1 8}}$.

Volgens die Christelike belydenis lui Jesus se opstanding die eindgebeure in. Die nuwe tydperk breek aan. Heil word 'n teenswoordige moontlikheid waar mense hulle met God laat versoen ${ }^{19}$. Sonder enige emstige krisis kon die vroeë Christene die verwagting dat die wêreldeinde naby is, laat vaar en beklemtoon dat mens die tye nie ken nie, maar altyd gereed moet wees. Schmithals oordeel dat ook die verwagting van die wederkoms van Christus die apokaliptiese siening oorskry omdat die komende Heer niemand anders is as die een wat gekom het nie en "der gegenwärtige Herr der Geschichte" is $^{20}$.

Waar Jesus Christus verkondig word breek die nuwe werklikheid aan te midde van die ou tydperk. Oud en nuut oorvleuel mekaar in die teenswoordige tyd omdat dit die strydperk is tussen die Ryk van God en die Ryk van die Satan.

Aanvaar die mens dat hy verlossing uit onheil nodig het - nie die onheil van die geskiedenis soos in die Apokaliptiek nie, maar sy eie onheiligheid - en waag hy dit om uit die genade van God te leef, breek die Ryk van God vir hom aan. Hierdie heil is volledig teenwoordig, maar dit bly dialekties ook volledig uitstaande omdat dit GOD se heil is en die mens dit nooit in sy besit het nie. "Christus bedeutet für den Glaubenden das Ende der alten Weltzeit in der Zeit, für den Nicht-Glaubenden die Verdammnis mitten in der Zeitlichkeit"21.

Die apokaliptiese dualisme van twee opeenvolgende tydperke 
word dus herinterpreteer as ' $n$ beslissingsdualisme wat te eniger tyd beslis word.

Waarom vind ons dan in die Nuwe Testament apokaliptiese voorstellings van die eindgebeure? Schmithals antwoord dat hierdie voorstellings die funksie het om teen entoesiastiese heilsekerheid te waarsku en om die moontlikheid oop te hou om van genade as geskenk van God te kan praat ${ }^{22}$.

Daar is ongetwyfeld raakpunte tussen die Apokaliptiek en die vroeg-Christelike oorlewering. Die vraag is hoe ons dit moet verstaan. Schmithals verskil hartgrondig van Käsemann se uitspraak dat die Apokaliptiek die moeder van die Christelike teologie sou wees. Inteendeel, "Die Überwindung der Apokalyptik en der Erfüllung der apokalyptischen Erwartung des Bevorstehenden Handeln Gottes ist die Mutter aller christlichen Theologie"23.

\section{SONDE}

Schmithals dring daarop aan dat daar in die kerk 'n duidelike begrip moet wees oor wat sonde werklik is, want "an der Auffassung dessen, was 'Sünde' ist, entscheidet sich zugleich was Gnade und Erlösung, was Heil und Wohl, kurzum, was christlicher Glaube überhaupt ist" ${ }^{24}$. As die kerk nie duidelik kan sê wat sonde is nie, sal al die gepraat oor verlossing en heil ook duister bly. As die wêreld dikteer wat onder sonder verstaan moet word en die sonde al kleiner en onskadelik voorstel of selfs ontken, dan speel hy ook met God klaar en word die mens al groter en groter. Die omgekeerde is ook waar: die kerk sal waaragtig genade verkondig, waar die sonde by die naam genoem word.

Schmithals slaag daarin om aan die hand van byderwetse slagspreuke die begrip sonde tuis te bring. Wat vandag alles onder emansipasie verstaan moet word, is nie duidelik nie, maar dit slaan veral op die bevryding van die mens van die las om die grond vir sy bestaan buite homself te soek.

Die geëmansipeerde mens is volgens Karl Marx die mens wat hom "um sich selbst und damit um seine wirkliche Sonne" sou beweeg ${ }^{25}$. Hierdie emansipasie is die moeder van hedendaagse emansipasie, van watter slag ook al. Hiermee land die mens onder die knegskap van die wet van selfverwerkliking, van eiegeregtigheid en selfbevryding $^{26}$. En dit is sonde. Want om sondaar te wees beteken om jou afhanklikhied van God te ontken, om jou eie Heer te wees, om 'n 
outonome bestaan te voer. Die mens as sondaar leef van sy eie prestasie, sy goeie werke. Hierdie ingesteldheid maak dat mense die een oomblik meen hulle gaan slaag en alles van hulself verwag en die volgende oomblik in wanhoop kan neersak omdat hulle vrees hulle gaan nie slaag nie $\mathrm{e}^{27}$.

'n Volgende hedendaagse woord wat kan dien om die gebeure van sonde te verduidelik, is identiteitsverlies. Met sonde in verband gebring, beteken identiteitsverlies dat die mens homself verloor, juis wanneer hy dink dat hy homself behou. In Markus 5:1-20 het ons 'n kunstige vertelling van die onmoontlikheid vir die mens om outonoom te wees. Die mens wat met God niks te doen wil hê nie, verloor homself aan demoniese magte. Die mens het nie 'n eie posisie tussen God en demoon nie, hy val in by die een of die ander. Die mens gee sy identiteit aan demone prys, waar hy sy rug op God draai $^{28}$.

' $n$ Derde begrip wat deugsame elemente bevat om die werklikheid van sonde te beskryf, is vervreemding ${ }^{29}$. Hierdie begrip het via Karl Marx sy slagspreukkarakter gekry en dit beskryf die vervreemding van die arbeider van die produk van sy arbeid soos dit byvoorbeeld onder die voorwaardes van loonarbeid geskied. Die uitgebuite mens is van homself vervreemd en in werklikheid nie waarlik mens nie. Hy moet tot ware mens in die klaslose gemeenskap gemaak word, waar die produk van sy arbeid aan hom teruggegee word. Formeel stem hierdie radikale siening van die vervreemde mens, wat nie waarlik mens is nie, maar dit eers moet word, ooreen met die antropologie van Paulus. Volgens Paulus is die mens van homself vervreemd omdat hy uit homself wil leef, omdat hy uit die werke van sy hande sy identiteit wil behou. Hierdie mens word eers waarlik mens as hy uit God lewe. Naas hierdie radikale aspek van Paulus se siening van vervreemding noem Schmithals die "geschichtlichen" aspek van vervreemding ${ }^{30}$. "Geschichtlich" beskryf die menselewe in die sin dat sy lewe in konkrete situasies op die spel is ${ }^{31}$. In hierdie oomblikke kies die mens in werklikheid nie dit of dat vir hom nie, maar hy kies of hy homself wil sien as Skepper van sy eie lewe of as skepsel van God. En vervreemding beteken dat die mens wil lewe, "die goeie wil", maar die kwaad tot stand bring, omdat hy van homself as skepsel van God vervreemd geraak het en homself as Skepper van sy eie lewe sien.

Vir Schmithals is die onderskeid tussen sonde, enkelvoud, en sondes, meervoud, van deurslaggewende belang ${ }^{32}$. 
Wat ons tot dusver beskryf het, val onder sonde, enkelvoud. Dit beskryf die mens as sondaar, die mens IS sondaar, hy doen nie bloot sondes nie. As sondaar leef die mens uit eie krag en nie uit God se ontferming nie. Hierdie sondige bestaan word op verskillende maniere gemanifesteer, byvoorbeeld in die roem op eie wysheid, op die vervulling van die wet, op die goddelikheid van jou eie gees, op die eie sekerheid van jou geloof. In 'n engere sin dui sonde op die oortreding van goddelike gebooie. En in hierdie sin word daar gewoonlik van sondes, meervoud, gepraat. Hierdie sondes kan getel en gelys word, terwyl sonde nie objektief aangetoon kan word nie, maar "geglo" word. Ons kry die interessantheid dat sonde sowel deur die roem op die vervulling van die wet as deur die oortreding van die wet gemanifesteer word.

Die natuurlike identifikasie van sonde met oortreding is ' $n$ baie ou verskynsel ${ }^{33}$. Dit stel die gemeenskap in staat om met strafmaatreëls dit by oortreders in te skerp dat dit of dat nie aanvaarbaar is nie. Maar die probleem is dat hierdie maatreëls die sonde as oorsaak van die sondes nie in ag neem nie en ook nie aan die sondaar laat reg geskied nie - al is daar hoeveel goeie dinge uit sy straf te leer. Want selfs die mees gebalanseerde maat van oordeel en genade van die kant van aardse geregtigheid kan die vervreemding van die mens nie ophef nie. Die gemeenskap kan sonde nie afskaf nie. "Nur wo die MACHT der Sünde gebrochen ist, findet die Sünde ihr Ende und der Sünder das Leben ${ }^{\prime 34}$.

Dit bring ons by Schmithals se beskouing dat die uitdrukking "vergewing van sonde" as aanduiding van die heilsgebeure nie toereikend is nie. Want "vergifnis" het in die gewone taalgebruik net op die verlede betrekking, terwyl dit tog om die onttroning van die sonde gaan "also um ein auch Gegenwart und Zukunft umfassendes Geschehen" ${ }^{\prime 35}$. Verlossing lei nie tot vergeet nie, maar tot dank $^{36}$.

Schmithals sê dat Paulus daarom die begrip "vergewing van sonde" vermy en in plaas daarvan van "bestaan in Christus" of van die "geregtigheid van God" wat aan die mens geskenk word, skryf $f^{37}$.

\section{HEIL}

Volgens Schmithals is die sogenaamde moderne mens gekonsentreerd met tegnologiese probleme besig, waarin die woord "God" geen funksie vervul nie, sodat die sin van hierdie woord maklik 
verdwyn ${ }^{38}$. Dit help ook nie om aan hierdie woord sin te probeer gee deur God as die hoogste wese of eerste oorsaak van alles aan te dui nie $^{39}$. Hierdie God "an sich" sal onverstaanbaar bly, veral waar die mens as produsent en verbruiker hom voortdurend in situasies bevind waar sy bestaan as MENS nie bevraagteken word nie. Die werklikheid van God kan net ter sprake gebring word in soverre dit die werklikheid van die mense raak, wat verder beteken dat God in werklikheid in beginsel vir mense verstaanbaar is. Die vraag na God kan nie losgemaak word van die alledaagse vrae van die mens na homself in die wêreld nie ${ }^{40}$. Die mens vra na die sin van die lewe, geluk, heil, na sy identiteit, na die begrensdheid van sy bestaan en dit is die eintlike - dikwels onbewuste - vraag na God ${ }^{41}$.

Maar Schmithals onderskei tussen hierdie soeke na heil van die "natuurlike" mens en die werklike heil self. Eers die ware heil maak duidelik waarna gesoek is. Sonder die vervulling in Christus sal die soeke na heil 'n blinde soektog bly ${ }^{42}$.

Schmithals onderskei twee maniere waarop heil in die Ou Testament verstaan is. Volgens die eerste word heil aan die empiriese grootheid "volk" of "Israel na die vlees" gekoppel. Hierdie binding van die goddelike heil aan ' $n$ historiese grootheid plaas die heil self onder druk van die sigbare, tasbare, beskikbare werklikheid. Die heil is dan "van hierdie wêreld" en die teokratiese ideaal vat hierdie heilsverwagting bondig saam" ${ }^{43}$.

Maar die geskiedenis van Ou-Testamentiese heil het toenemend 'n onheilsgeskiedenis geword omdat die bewakers van die heil dit verduister deur die mens as die oorsprong van die heil voor te hou ${ }^{44}$. Volgens die tweede Ou-Testamentiese opvatting oor heil kan dit nie in ' $n$ konkrete iets of 'n toestand vasgevang word nie, want dit bestaan nie in "iets" nie, maar in "iemand"45.

Schmithals haal in hierdie verband ps 27:1 aan:

"Der Herr ist mein Licht und mein Heil;

vor wem sollte ich mich fürchten!

Der Herr ist meines Lebens Kraft;

vor wem sollte mir grauen!"46

Jesus Christus bring ook nie 'n nuwe, ander heil nie. Hy bring eens en vir altyd die een, ou heil weer nuut. Hierdie heil bestaan nie in dit of dat nie, maar in God self ${ }^{47}$.

'n Mens kan hierdie heil net soos 'n KIND ontvang, want 'n kind se toekoms bestaan nie in dit of dat nie, nie uit sy planne of presta- 
sies of mislukkings nie, maar daarin dat hy gedra word en ten spyte van die donker en uitsigloosheid die doel bereik ${ }^{48}$.

Heil beteken die wonder van God se teenwoordigheid in hierdie wêreld van frustrasie en dood ${ }^{49}$. Dit bring 'n einde aan die vervreemding van God. Dis volkome hulp. Die grond vir die mag van my vervreemding van God lê daarin dat ek sonde doen, so lê die grond vir my heil in God. God het die grond vir my heil in die eenmalige historiese gebeurtenis, in Jesus Christus gelê; Golgota is "Ort des eschatologischen Heils" ${ }^{10}$; daarom kan ek op geen manier self hierdie grondslag lê nie. Heil bestaan net met betrekking op die heilsgebeure, wat van goddelike inisiatief uitgaan ${ }^{51}$. Heil gebeur waar ek nie meer in die waan leef dat ek van God ontgroei het nie, maar op Hom aanspraak maak omdat Hy op my, die sondaar, aanspraak maak. Heil kan nooit iets wees waaroor ek beskik nie, want so word dit ' $n$ menslike moontlikheid en dit beteken onheil ${ }^{52}$.

Daarom praat Schmithals van die woestyn as die "Ort des Heils"53. Dit staan vir die heilsame einde van alle menslike moontlikhede. Om te beklemtoon dat dit GOD se heil is wat alle menslike kragte te bowe gaan, gebruik Schmithals die uitdrukking "nog nie". Hierdie heil kan nie deur mense gemanipuleer word nie en in hierdie sin bly dit geheel uitstaande ${ }^{54}$. Maar ons mag ook nie die "alreeds", die "Voraus des Heils" prysgee nie. Die Nuwe Testament verkondig die paasgebeure nie as belofte nie, maar as vervulling. As ons hierdie Nuwe-Testamentiese reël nie volg nie, vervang ons die evangelie deur die wet soos in die hedendaagse teologie die geval is. Dan word die mens die heildraer ${ }^{55}$.

Schmithals hou dus sowel by die "nog nie" as die "alreeds" daaraan vas dat dit GOD se heil is en dat die heil volkome is.

Schmithals bring die hedendaagse gebrek aan pneumatologie in verband met wat hy'n verlies aan Christologie noem. In die plek van die Bybelse Christus het die "historiese" Jesus gekom, in die plek van die heilsverkondinging die hoop op heil. "Das Bekenntnis zum Geist, das heisst zu dem durch Jesus Christus schon gebrachten Heil, verstummt ${ }^{\prime 56}$.

In die vroeë kerk het daar verskillende teorieë bestaan oor hoe God die mag van die sonde gebreek het. Schmithals noem hulle: die Ou-Testamentiese-Joodse voorstelling van die soenoffer, die plaasvervangingsgedagte; die gnostiese skema van vernedering-verhoging; die mistieke voorstelling van "sterwe met Christus" is dit nie ' $n$ teorie wat die ding doen nie, want die mens kan nie op 
'n afstand toeskouer wees van hoe sy sonde onttroon word nie. Die mens kan net eksistensieel betrokke wees by die veroordeling van die sonde in sy lewe. Die onmag van die sonde word VIR MY deur die verkondigde Woord blootgelê en hierdie bevrydende Woord is die werklike uitdrukking van die heilsgebeure ${ }^{58}$. Die "Woord van versoening" is nie net 'n woord wat van versoening vertel nie, dis die versoenende Woord. Jesus is in hierdie Woord in verhoog, wat versoening voltrek, want verhoging in die raamwerk van die antieke wêreldbeeld beteken nie plekverandering nie, maar erkenning van goddelike outoriteit. Die GEKRUISIGDE Christus het hierdie outoriteit en waar die versoening met God deur die verkondiging van die gekruisigde plaasvind, is die "verhoogde" Heer teenwoordig".

Die kerk leef uit hierdie "Woord van versoening". In die kerk word hierdie Woord verkondig en aangeneem. In hierdie sin noem Schmithals die kerk "der Ort der Freiheit und des Friedens, der Freude und des Lebens, der Wahrheit und der Erkenntnis, des Heils und der Rettung" ${ }^{\prime 60}$.

Schmithals is nie daarmee tevrede om geloof as 'n voorbereiding of voorwaarde om die heil te ontvang, te beskou nie. Die geloof red. Die geloof self is die heil, want in geloof gryp die mens na die uitgestrekte hand van God ${ }^{61}$. Hiermee hang saam dat heil nie 'n toestand sonder gevaar en beslissing is nie. "Heil begegnet vielmehr als die geschichtliche Möglichkeit, sich dem alten Aon nicht mehr gleichstellen zu müssen"62.

\section{GELOOF}

Schmithals kan kort en bondig verklaar: "'Glauben' heisst, die Botschaft des Evangeliums annehemen" ${ }^{\prime 63}$.

Dit beteken dat die mens insien dat hy met sy eiegeregtige besigheid - sy alledaagse ervaring, sy kennis en kundigheid - hulpeloos, verlam, siek, blind, dood bly. Daar is niks "warauf er sein Leben gründen könnte" ${ }^{\prime \prime 4}$. En hierdie mens waag dit om sy lewe as geskenk van God te ontvang. Geloof maak op God aanspraak ${ }^{65}$.

Hierdie opvatting oor geloof verskil van die siening waarvolgens geloof beteken om dinge wat nie te bewys is nie vir die waarheid te hou. Geloof is nie 'n eksperiment van die verstand nie, "sondern wagender Einsatz des Lebens" ${ }^{\prime 66}$.

Schmithals waarsku dat geloof nie as 'n godsdienstige prestasie gesien moet word nie. In Markus 9:24 staan die "Pauliniese" bely- 
denis: "Ich glaube, Herr; hilf mir in meinem Unglauben." Die geloof van hierdie man bestaan daarin dat hy by homself net ongeloof sien, net die onwilligheid om God God te laat wees en daarom bid hy om geloof as geskenk te ontvang en ontvang hy dit $0^{6}{ }^{68}$. Hierdie gelowige ontvang nie dit of dat nie, vir hom is alles moontlik, dit wil sê, hy is van sonde verlos, hy wat dood was, het weer lewend geword en in soverre het hy deel aan die almag van God $^{69}$. Schmithals beskryf Jesus se woorde "Was soll das 'Wenn du etwas kannst'?! Dem, der glaubt, ist alles möglich!" as van die "theologisch stärksten und gewagtesten Aussagen des ganzen Neuen Testaments"70.

Schmithals onderskat ook nie die mag van die sonde nie, daarom kan geloof nie op 'n toestand dui vanwaar 'n mens nie weer kan uitval nie. Paulus praat van "WANDEL im Geist" en Johannes van "BLEIBEN in Christus" om die misverstand van 'n "SEIN in Christus" te vermy. Schmithals druk dit so uit: "Es gibt keine Heilssicherheit, sondern nur die Heilsgewissheit derer, die 'im Geist' unterwegs bleiben"71. Hierdie "Heilsgewissheit" bewaar die gelowige van alle onsekere fanatisme en gee aan hom die gelatenheid van een wat in die wêreld is, maar nie van die wêreld nie. Want dit is nie ons eie oordeel of omstandighede wat ons stand bepaal nie, maar God se oordeel, "das Ja Gottes zu uns inmitten aller bedrängenden Mächte" ${ }^{\prime \prime 2}$.

\section{HOOP}

Saam met Paulus beskryf Schmithals die bestaan van die gelowige net in teenstellings: "als die sterbenden - und siehe, wir leben; als die Traurigen - ober immerfort fröhlich"73.

Die "alreeds" en die "nog nie" moet saam vasgehou word. Die "nog nie" bewaar ons teen 'n entoesiastiese heilsekerheid en teen 'n algemene wanhopigheid. Redding waarin die hoop agter die rug lê, is geen redding meer nie. Die "alreeds" bewaar ons daarvan om nie die redding op hoop te verander na hoop op redding $n_{i e}{ }^{74}$.

Paulus konkretiseer die "Hoffnungsgut" as die verlossing van die liggaam, sonder om die onsigbare sigbaar voor te stel. Schmithals interpreteer dit so dat Paulus hom nie ' $n$ liggaamlose bestaan voorstel nie, maar die verlossing van die "liggaam van hierdie dood". Hierdie "liggaam" dui op die blywende verbondenheid aan die ou wêreld sodat die gelowige die heil net te midde van doodslyding ervaar. Daarom sug hy na die nuwe liggaam waarin "die 'Kinder Gottes' das 'Erbe' antreten werden"75. 
Schmithals wil ook nie die VOORSTELLING van die opstanding uit die dood absoluut stel nie. Dit sou 'n poging wees om die onsienlike sienlik voor te stel $^{76}$.

Ook Jesus wys in sy gesprek met die Sadduseërs enige voorstelling van die opstanding van die hand, maar lê klem op die "Kraft Gottes" ${ }^{\prime 7}$.

Schmithals onderskei tussen die Christelike hoop en utopie. Utopie is op IETS gerig, 'n toestand, terwyl hoop op IEMAND gerig is, 'n persoon ${ }^{78}$. Die Christelike hoop hoop nie op iets nie, maar op God. Schmithals haal uit ps 139 aan:

"Fuhre ich gen Himmel, so bist du da.

Bettete ich mir in die Hölle, siehe, so bist du auch da."

En hy voeg Luther se opsomming daarby: liewer met God en deur God in die hel as sonder God in die hemel ${ }^{79}$. In die lig hiervan lees Schmithals al die utopiese beelde van hoop in die Bybel. Uit die verskillende beelde wat gebruik word kan daar nie 'n samehangende voorstelling gemaak word nie en verder verwys die kern van al die beskrywings na God self. Byvoorbeeld die "utopistiese" Openbaring van Johannes omsluit alles wat hy te sê het met: "ICH bin das A und das $O$, der Erste und der Letzte, der Anfang und das Ende" ${ }^{\prime 80}$. Dat ons HOOP, op God hoop, beteken meer as al die inhoude van alle utopieë tesame ${ }^{81}$. Utopie sny die hoop af, want dit eindig in 'n toestand. Daarenteen bly ware hoop sonder einde. Dit bly oop vir die nuwe, onbekende wat God gee. Die gelowige reisiger weet dat hy nêrens anders kan uitkom as daar waar God op hom wag nie ${ }^{82}$.

Schmithals word nie moeg nie om te beklemtoon dat die Christelike hoop swygsaam is ${ }^{83}$. Hierdie hoop is onbesorg oor die toekoms van God en het sy hande vry om in die teenswoordige werksaam te wees. Die utopis het geen oog vir die hede nie, want hy is droomverlore oor die toekoms. Die hede behoort aan hulle wat op God hoop, want hulle behoort vir altyd aan God $^{84}$.

\section{LIEFDE}

Volgens Schmithals moet ons onder liefde nie 'n gevoel verstaan nie. God se liefde vir ons kan net as daad ${ }^{85}$ reg begryp word. Schmithals haal Johannes 3:16 aan: "God het die wéreld so liefgehad dat Hy sy enigste Seun gegee het, sodat dié wat in Hom glo, nie verlore sal gaan nie, maar die ewige lewe sal hê." Net so min is ons liefde vir 
God 'n gevoel of selfs 'n "kultiese" diens aan God. In Markus beteken ons liefde vir GOD dat ons ons NAASTE sal liefhê wat daad beteken $^{86}$.

Wat ons in die liefde te doen staan, kan ook nie uit bepaalde Christelike norme afgelei word nie, dit volg eerder algemeen menslike riglyne: "das Leben des Menschen zu fördern" ${ }^{87}$. Schmithals beklemtoon dat die regte optrede nie deur "hoëre" ideale bepaal kan word nie. Dan sou ons te veel wil doen en self die Ryk van God wil afdwing. Die nood van die oomblik is belangriker as ons hoë ideale. Daarom word die riglyn vir ons optrede so onoortreflik algemeen en "profaan" in Markus 3:4 geformuleer: "Gutes tun, Leben retten"88. Geen geloofsgenoot mag in sy liefde deur 'n ongelowige in die skande gesteek word nie. "Ein barmherziger Samaritaner staht dem ewigen Leben näher als ein unbarmherziger Glaubensgenosse ${ }^{\prime 89}$.

Schmithals laat ook nie die "goed doen" van die gelowige in die lug hang nie. $\mathrm{Na}$ aanleiding van Romeine 12:9-21 en 1 Korintiërs 13:4-7 merk hy op dat liefde nie 'n hoeveelheid van goeie dinge is wat ek aan my naaste moet bewys nie, dit sou te veel na ons moderne prestasie-honger klink. Die liefde word eerder "passief" beskryf: die klimaat waarin die liefde gedy word nie deur my voorstelling van wat vir hom goed is bepaal nie, "sondern van der Freiheit, mit der ich dem anderen erlaube - Paulus denkt primär an den christlichen Bruder - er selbst zu sein" ${ }^{\prime 90}$. Met so 'n passiewe liefde word die kwaad deur die goeie oorwin. Hierdie duldende liefde stel groter eise aan ons as die handelende liefde.

Liefde is die manier waarop die gelowige met sy naaste omgaan. Die lewe in liefde, net soos die lewe in geloof is nooit afgehandel nie. Schmithals beklemtoon op grond hiervan dat liefde dus nie 'n gebod kan wees wat mens kan nakom en afhandel nie, ons bly dit aan mekaar skuldig. Daarom formuleer Paulus met opset in Romeine 13:9 die "woord" van die liefde. Schmithals wil nie vertaal met "Jy MOET jou naaste liefhê soos jouself" nie, maar verkies: "Du kannst (darfst, wirst) deinen Nächsten lieben" ${ }^{\prime 91}$.

By Schmithals moet ons dus van liefdesetiek of vryheidsetiek praat. Dit moet skerp onderskei word van 'n gesindheidsetiek. Ons optrede word nie daaraan gemeet of ons gesindheid goed is nie, maar of ons in 'n bepaalde situasie kundig en saaklik was. "Die Kirche hat den Auftrag, durch die Predigt des Evangeliums den Menschen in jene Freiheit des Glaubens zu führen, in der er sich vernünftig und sachlich der Dinge dieser Welt annehmen kann"92. 


\section{WONDER}

Schmithals val nie in by die algemene gebruik om van NUWE-TESTAMENTIESE wonders te praat nie ${ }^{93}$. Hy haal Luther aan wat die Evangelie van Johannes, Paulus se briewe, veral die een aan die Romeine, en Petrus se eerste hoofstuk vir die meeste lees aanbeveel, want "in diesen findest du nicht viel Werk und Wundertaten Christi beschrieben, du findest aber gar meisterlich ausgestrichen, wie der Glaube an Christum Sünde und Tod und Hölle überwindet und das Leben, Gerechtigkeit und Seligkeit gibt"94.

Binne die Oer-Christendom was daar dus glad nie eenstemmigheid dat wonders ' $n$ geslaagde manier is om die evangelie te verkondig nie. Paulus trek self daarteen te velde: "Die Jode vra wondertekens en die Grieke soek wysheid, maar ons verkondig Christus wat gekruisig is." Schmithals formuleer die gevaar wat Paulus sien as die valse veronderstelling van die mens wat meen hy kan God - die ware God - ontmoet, sonder om Hom te gehoorsaam, hy kan in hierdie ontmoeting dieselfde bly as wat hy nog altyd was. "Das Wunder zerschlägt den Menschen nicht, um ihn ganz der Gnade Gottes zu öffnen, sondern lässt ihn des Göttlichen konstatierend ansichtig werden"

Ten spyte van hierdie gewigtige beswaar was wonders tog 'n integrale deel van die antieke wêreldbeeld. Die moontlikheid dat allerhande magte in die gang van sake kan ingryp was altyd oop. Vir die antieke mens was dit nie 'n vraag of wonders gebeur of nie. Hy het dit aanvaar sonder om 'n geloofsaak daarvan te maak'. Dit was nie as ' $n$ bewys vir geloof gesien nie. Daardie mense kon nie en sou nie anders op ' $n$ wondervertelling as op 'n blote mededeling reageer nie. Vir die vroeë kerk het wondervertellings net nog 'n moontlikheid gebied om die evangelie op 'n verstaanbare manier te verkon$\mathrm{dig}^{97}$. Die wonderberigte bestaan deurgaans uit drie dele: Eers word die nood van die mens geskilder, daarna die oorwinning oor die nood deur Jesus en laastens word van die reaksie van die mense vertel. Vir Schmithals is dit glad nie toevallig nie dat hierdie driedeling ooreenkom met die DOGMATIESE skema van: "Sunde - Heilswerk - Glaube und Heiligung"98. Die berig oor die stilmaak van die storm is nie bedoel om skipbreukelinge te troos met die oplossing dat God ook uit seegeweld sou red nie. Die demoonuitdrywing is nie bedoel om te sê dat God van besetenheid en waansin sou kon red nie. Hierdie enkele tekens en kragtige dade van Jesus weerspieël 
eerder die HELE evangelie: Jesus Christus het gekom om sondaars te red; in Jesus Christus het God die wêreld met Homself versoen"9.

Die vraag in verband met die wonderverhale kan nie wees of dit wat vertel word destyds werklik so gebeur het nie. Hulle waarheid hang daarvan af of dit wat hulle verkondig vandag gebeur. Hulle verkondig die TEENSWOORDIGE Heer. Die vraag in verband met die wonderverhale is dus die vraag na onsself, na die waarheid van ons eie lewe ${ }^{\mathbf{1 0 0}}$. Die werklike wonder is dat mense die Woord van God kan hoor en gehoorsaam - die Bybel noem dit geloof - dit is die wonder van die nuwe lewe uit God se genade, die wonder van vryheid van angs en vrees, die wonder van om getroos te lewe en te sterwe, die wonder van liefde sonder voorbehoud teenoor elke medemens ${ }^{101}$.

\section{DIE KERK}

Vir Schmithals is die kerk, soos wat hy homself verstaan, nie 'n sosiale, empiriese grootheid nie. Die kerk is die gemeenskap van die gelowiges. Die kerk het homself nie begin nie en kan homself nie ontbind nie. Die hoeksteen is al voor die grondlegging van die wêreld gelê, Jesus Christus ${ }^{\mathbf{1 0 2}}$. Die kerk word deur die Woord van die evangelie gekonstitueer en nie deur die kerkwet of een of ander juridiese bevoegdheid nie $\mathrm{e}^{\mathbf{1 0 3}}$. Omdat Christus mense deur sy Woord ontmoet kan Schmithals die funksie van die kerk soos volg formuleer: "Wo die Gemeinde recht verkündigt, spricht sie nicht ÜBER Wort und Wirken Jesu, sondern TUT sie sein Wort und sein Werk"104.

Sedert die Verligting word kerk en godsdiens aan hulle nut vir die samelewing gemeet. Godsdiens word voorgestel as die bedrieglike uitvinding van die priesterklas of as steunpilaar vir die belange van die heersende groep ${ }^{105}$. Hierby kom nog die enger terrein van die kerksosiologie wat byvoorbeeld 'n funksieverlies van die kerk vasstel in vergelyking met die tydperk toe die kerk oor die hele landskap getroon het. Daar word voorstelle gemaak oor hoe die kerk sy verlore aansien kan herwin: identifiseer teikengroepe, bring hulle in verenigings bymekaar, verander die erediens in ' $n$ dialoog, ens ${ }^{106}$.

Schmithals is oortuig dat die kerk hom deur hierdie voorskrifte laat meevoer het om toe te laat dat hy nie volgens sy eie maatstaf en grondslag gemeet word nie, maar van buite gedikteer word ${ }^{107}$. In plaas van die Bybelse Christus-getuienis laat die kerk hom byvoor- 
beeld deur die historiese roeping van 'n volk lei ${ }^{108}$. Die kerk hoop om so aan die sosiale verwagtinge te voldoen.

Wat die enger terrein van die binne-kerklike situasie betref ontdek die kerk telkens dat die vorm waarin die kerk werk nie bloot 'n kwessie van goeie of slegte organisasie is nie, maar dat dit van die saak afhang wat georganiseer moet word. Dit word dus onmiddellik 'n teologiese probleem. Solank die kerk, kerk wil bly, meet hy hom aan sy saak en sy spesifieke opdrag ${ }^{109}$.

Dis verder van belang dat Schmithals onderskei tussen die kerk en die gelowige. Die kerk neem leerbeslissings en roep op tot geloof en geloofsdade. Maar "die kerk" glo nie self nie, tree ook nie self in geloof op nie, ontvang ook nie vergewing van sondes nie. Dit doen gelowiges $^{110}$. "Insofern ist die Theorie der KIRCHE die Theologie, ihre Praxis die Predigt; die Theorie des CHRISTEN aber ist das gehörte Wort, seine Praxis der gelebte Glaube"111.

Hierdie siening het die belangrike gevolg dat die politieke verantwoordelikheid in die wêreld deur die gelowige onderneem word wat deur die verkondiging daarvoor toegerus is en nie deur "die kerk" in die raamwerk van een of ander Christelike politiek nie ${ }^{112}$.

\section{NAGMAAL}

In verband met die ou strydpunte of die brood en wyn 'n WESENSVERANDERING in liggaam en bloed van Christus ondergaan, of die liggaam en bloed van Christus, IN, MET EN ONDER die brood en wyn teenwoordig is en of die brood en wyn sy liggaam en bloed BETEKEN oordeel Schmithals dat hierdie antwoorde op die valse veronderstelling berus dat die instellingswoorde van die substansies, liggaam en bloed van Christus, praat. In werklikheid staan "liggaam en bloed" vir die "dood van die Here", vir die kruisgebeure. Die gemeente wat die brood eet en uit die beker drink, kry aandeel aan die heilsgebeure van die kruis ${ }^{113}$.

Die "doen dit tot my gedagtenis" van 1 Korintiërs 11 hou volgens Schmithals die gevaar in dat die kruisgebeure as 'n afgehandelde gebeurtenis in herinnering geroep moet word. Die teenwoordigheid van gekruisigde word gereduseer tot 'n herinnering aan Hom. Daarom begrond Paulus die herinnering in vers 26 met "julle VERKONDIG die dood van die Here". In die nagmaal as verkondiging word die kruis van Christus aangedui as die grond en werklikheid van die TEENSWOORDIGE heil. In die verkondiging geskied die 
versoening ${ }^{14}$. Die "totdat $\mathrm{Hy} \mathrm{kom"} \mathrm{is} \mathrm{volgens} \mathrm{Schmithals} \mathrm{uitdruk-}$ king van die eskatologiese voorbehoud, "das Abendmahl vor dem Missverständnis zu bewahren, ein Mysteriemahl zu sein, das die Teilnehmer, vergottet, und lässt es die Verkündigung DES Heils bleiben, das auf Hoffnung gewährt wird"115.

Die nagmaal het volgens Schmithals drie karaktertrekke: die soteriologiese, ekklesiologiese, en eskatologiese. Van hierdie drie is die soteriologiese die belangrikste omdat dit nêrens waar die nagmaal in die Nuwe Testament ter sprake is, uitgelaat is nie. Die ekklesiologiese en eskatologiese word aan die soteriologiese verbind, wat beteken dat "die Bruderschaft und die Hoffnung der Gemeinde gründen im heilbringenden Christusgeschehen"116.

Die vroeë kerk is deur die viering van nagmaal gekonstitueer en het hulleself nie gesien as 'n gemeente wat deur lidmate gevorm word nie ${ }^{117}$. Kerkloosheid en nagmaalloosheid was identies.

Schmithals wys daarop dat kinders van die begin af as lidmate van die gemeente beskou is en dat hulle inderdaad nagmaal gevier het ${ }^{118}$. Die "drink almal daaruit" (Mt 26:27), is 'n aanduiding daarvan". Later is in die Westerse Kerk die heiligheid van die elemente so sterk beklemtoon dat kinders van die nagmaal weerhou is omdat hulle byvoorbeeld die wyn sou mors en dit dan ontheilig. Nog later is daar vereis dat die nagmaalgangers die onderskeidingsvermoë moet hê om die liggaam en bloed van die Here van ander kos te onderskei.

Die Reformatoriese Kerke het hierdie gebruik geërf en tot vandag toe verleen aanneming toegang tot die nagmaal en volle lidmaatskap van die kerk. Schmithals oordeel dat dit neerkom op 'n "Verrechtlichung der Konfirmation im Rahmen einer Mitglieder - Kirche" en in plaas daarvan dat dit mense in die nagmaalsgemeente inlei, lei dit eerder uit die kerk uit ${ }^{120}$. Dit mag wees dat reformatoriese kerke nagmaalsviering vir kinders uitgesluit het om nagmaalgang met kerklike tug te verbind. Aangesien die kerklike tug in die praktyk verval het, lei die verbinding van kategese met aanneming tot "Intellektualiserung und zur Verrechtlichung" van die nagmaal ${ }^{121}$. Hierdie intellektualisering is nie regverdigbaar nie omdat mens in die eerste plek nie die nagmaal VERSTAAN nie, maar as heilige maal ERVAAR, wat verstaan insluit, veral as verstaan beteken om jouself uit die nagmaal te verstaan. Verder word mens nie na die erediens genooi OMDAT jy verstaan nie, maar SODAT jy verstaan, wat ook vir die nagmaal behoort te geld ${ }^{122}$. 
Schmithals dink nie dat deelname van kinders aan die nagmaal die volkskerklike lidmaatgemeente na 'n nagmaalsgemeente gaan verander nie. Die beste sou wees om die regte gemeente as voorveronderstelling vir die deelname van kinders aan die nagmaal te sien. Intussen sal dit goed wees as ouers hul kinders gereeld kerk toe bring en saam met hulle nagmaal vier. Maar die deelname van kinders aan die nagmaal bly nog "bis auf weiteres die Ausnahme"123.

\section{DOOP}

In verband met die doop neem Schmithals 'n besondere standpunt in wat die moeite werd is om van nader te bekyk. Dit kom daarop neer dat die vroeë Christendom ons heftige debatte oor die doop nie reflekteer nie omdat hulle ' $n$ vanselfsprekende oplossing gehad het. Doop het vir hulle in verband met sendingwerk gestaan. Die Nuwe Testament verbind telkens die sendingbevel aan die doopbevel. Daarom het hulle die mense wat deur die verkondiging tot geloof gekom het in die gemeente ingedoop. Geloof en doop vorm twee kante van dieselfde saak: "Der Glaube bewirkte das Heil des Einzelnen; die Taufe liess erkennen, dass es dies Heil nur in und mit der Gemeinde und durch sie gab"124. Wanneer 'n huis of 'n familie tot geloof gekom het, is die kinders ook vanselfsprekend "unter den Segen der Taufe gestellt"125.

Wat sou die vroeë Christene gemaak het met kinders wat gebore word uit 'n gesin wat reeds aan die kerk behoort? Schmithals meen dat hulle glad nie gedoop is nie, want dit is nie die doop wat heilsnoodwendig is nie, maar die behoort aan die gemeente, wat deur die doop bemiddel is. Kinders van gelowige ouers was vanselfsprekend as lidmate van die gemeente beskou. "Wer in die christliche Gemeinde hineingeboren wurde, brauchte nicht auch noch in sie hineingetauft zu werden"126.

Volgens die antieke korporatiewe denke sluit die oorspronklike doopsolidariteit ook die wat nog gebore moet word in. Hulle geld ook as gedoop ${ }^{127}$.

Wat die praktyk vandag betref meen Schmithals dat ons nie die hedendaagse individualisme eenvoudig uit die pad kan vee en terugval in die korporatiewe denke nie. Die moontlikheid om nou 'n Christen sonder doop te wees bestaan prakties nie.

Ons individualisme veroorsaak ook die krisis van die kinderdoop omdat die suigelingsdoop ' $n$ Christelike huis en selfs ' $n$ Christelike gemeenskap veronderstel. 
Daarom moet die doop van volwassenes as ewe geregverdig langs die suigelingsdoop staan. So iemand kom dan nie uit die heidendom nie, maar uit 'n na-volkskerklike gemeenskap ${ }^{128}$. Ouers wat hulle huis as 'n Christelike gemeenskap verstaan, doen goed as hulle hul kinders laat doop. Schmithals sien die "geloofsdoop" wat in baie Vrye Kerke gepraktiseer word as 'n produk van die individualisme. Vir CHRISTENE kan geloof die doop nie moontlik maak nie en dis 'n oorskatting van die doophandeling as CHRISTENE daardeur eers tot volle lidmate van die kerk word.

Ten slotte hou Schmithals vol dat dit teologies gebiedend is om byvoorbeeld iemand wat in die bedenklike praktyk van geloofsdoop grootgeword het en daarom vir die doop bang is, as volle lidmaat van die gemeente te erken sonder dat hy gedoop word ${ }^{129}$.

\section{DIE FUNKSIE VAN DIE BYBELSE TRADISIE}

Die kerk en die evangelie het aanvanklik 'n hele ruk sonder die Bybelse teks bestaan. Met verloop van tyd is die evangelie of Woord van God in die tekste opgeneem waarin dit telkens onder bepaalde omstandighede aan die destydse hoorders uiteengesit is. Die Bybelteks is nie dieselfde as die evangelie nie, maar die evangelie kom nie anders tot ons as in die vorm van tekste nie.

Hoekom beroep die kerk hom vir sy bestaan, sy diens en verkondinging op hierdie evangeliese tekste en moet dit as norm beskou word? Die Gnostiek byvoorbeeld het dit nie nodig nie, want waar die Gees direk in en uit geïnspireerdes praat, is so 'n tradisie nie nodig nie. Die kerk veroorloof hom nie hierdie vryheid nie, maar maak op die apostoliese oorlewering staat omdat sy boodskap aan 'n bepaalde plek gebonde is en 'n bepaalde historiese gebeurtenis as grond het. Hierdie gebeurtenis is die geval (Geschick) van Jesus van Nasaret, sy menswording en kruisdood ${ }^{\mathbf{1 3 0}}$. Die hoeksteen van kerk en teologie is nie 'n idee nie, maar Jesus van Nasaret ${ }^{131}$. Net sy geval word in die vroeg-Christelike verkondiging verduidelik. Ook die $\mathrm{Ou}$ Testament word gelees as getuienis vir die geloof in Jesus Christus. Schmithals wys daarop dat die wederkoms van Christus nêrens deel van die heel oudste geloofsbelydenisse was nie en dat die drieledige vorm van belydenis eers later met die toevoeging van "God" en "Gees" gestalte gekry het, wat beklemtoon hoe stewig die evangelie histories bepaald is ${ }^{132}$. Op hierdie eenmalige gebeurtenis, die middelpunt van die Nuwe Testament, is die kerk gegrond. Die 
kerk het hom nie deur sy geloof in God die Skepper van die Jodedom onderskei nie, maar deur sy belydenis dat Jesus die Messias is.

Maar ons kan onsself nie direk aan die sogenaamde heilsfeite bind nie. Want as feit beteken die geboorte of kruisiging van Jesus niks meer as enige ander geboorte of teregstelling nie. Vir hedendaagse mense is dit onmoontlik om die feitelikheid van die opstanding of hemelvaart te aanvaar, behalwe vir fundamentaliste wat van heilsfeite praat asof dit dieselfde as natuurwetenskaplike feite is. Die vraag is eerder waarom en hoe en waarvoor die geval van Jesus van Nasaret verkondig word ${ }^{\mathbf{1 3 3}}$ ? Waarom? Omdat die eerste Christene Jesus se menswording, sterwe, opstanding en verhoging as goddelike heilsdaad ervaar en verstaan. Hoe? Hulle gebruik bekende begrippe van daardie tyd soos Christus, Seun van God, Here, om te sê dat Jesus aan die verwagtinge wat in hierdie begrippe tot uitdrukking kom, voldoen. Waarvoor moet dit verkondig word? Omdat die gebeure self eenmalig en onherhaalbaar is, het dit ' $n$ teks nodig om daarvan te getuig. Omgekeerd is die BYBELSE teks die bewys vir die eenmaligheid en onherhaalbaarheid van die gebeure en verder is hierdie teks die grootste kampvegter vir hierdie waarheid. Die kerk kan nie van die Bybelse woord afsien sonder om tegelyk van die eenmalige geval Jesus van Nasaret af te sien nie. So kwalifiseer die Bybelse woord sy werklike inhoud as goddelike heilsdaad, want geen menslike daad kan daarop aanspraak maak dat dit net in die getuienis van oorlewering werksaam sou wees nie ${ }^{\mathbf{1 3 4}}$.

Met die vasstelling van die kanon het die verskillende groepe hul spesifieke geskrifte ter tafel gelê en met die keuse wat die kerk gemaak het wou hulle hulself veral teen die Gnostiek afgrens ${ }^{135}$. Die kanon is dus uitdrukking van ekumenisiteit en alleengeldigheid.

Deesdae is die insig dat die grense van die kanon oop is, feitlik onbestrede. Maar dit beteken nie dat die kanon van Nuwe-Testamentiese geskrifte verander moet word of selfs verander kan word nie, want die ander kerklike geskrifte word aan die kanon gemeet en jy vervang nie eerstehandse bronne deur tweedehandse bronne nie $^{136}$.

In werklikheid is die kanon dus onvervangbaar om die oerChristelike boodskap oor te dra. Die openheid van die kanon word deur die kritiek binne die kanon bewaar. Mens kan hier byvoorbeeld dink aan die manier waarop Schmithals verskillende NuweTestamentiese uitsprake oor die owerheid hanteer ${ }^{137}$. Schmithals soek nie na 'n kanon binne die kanon nie, want dit sal 'n versame- 
ling van lieflingtekste wees. Wat gedoen moet word, is om besig te bly met die fondament wat al die eeue die kerk gedien het.

\section{DIE UITLEG VAN DIE BYBELSE TRADISIE}

Uit die belangrikste plek wat Schmithals aan die Nuwe-Testamentiese kanon toeken, spreek dit vanself dat hy teologie as skrifuitleg beskou en beoefen. Met die interpretasie van die Bybelse tradisie staan en val die teologiese taak van die kerk, daarom is hermeneutiek "die eigentliche Arbeit der Theologie"138.

Die hermeneutiese probleem bestaan daarin dat ons in die eerste plek met die Bybel te doene kry as 'n historiese dokument, byna 2000 jaar oud. Bloot hierdie feit maak dat hierdie tekste vir mense van vandag in ' $n$ mindere of meerdere mate onverstaanbaar is. Die histories-kritiese eksegese het hierdie probleem ontdek en probeer om dit op te los ${ }^{139}$.

Maar dit is volgens Schmithals ook moontlik om teologie te beoefen sonder om van die hermeneutiese probleem bewus te wees of daarvan rekenskap te gee. Luther en Barth kon dit regkry omdat hulle die dogmatiese middelpunt van die Skrif as uitgangspunt geneem het, Luther met die regverdigingsleer en Barth met die uitspraak dat God God is en nie ' $n$ mens nie. Bultmann kon byvoorbeeld kla oor die manier waarop Barth vir Paulus verstaan, maar nooit ontken DAT hy hom verstaan nie. Vir die onhistoriese eksegese van Barth is die probleem nie: Hoe verstaan 'n mens die Bybelse tradisie nie, maar eerder: hoe kom dit dat iemand dit verkeerd verstaan? Vir die historiese eksegese, wat met Semler begin en in Bultmann 'n hoogtepunt bereik, is die vraag: Hoe verhoed ek dat ek verkeerd verstaan ${ }^{140}$ ?

Schmithals voel hom heeltemal tuis by die historiese benadering van Bultmann. Volgens hierdie benadering word die Bybelse tekste nie as tydlose, dogmatiese leerstukke beskou nie. Die tekste word as HISTORIES beskou, wat beteken dat daar ' $n$ aanleiding was waarom dit geskryf is en dat 'n bepaalde doel daarmee bereik wou word ${ }^{141}$. Schmithals meen byvoorbeeld dat Romeine 1-11 geskryf is omdat die Jode die Godvresendes onder druk geplaas het deur te verkondig dat hulle Jode moet word om die heil te ontvang. Paulus skryf dat die geregtigheid uit die GELOOF die onderskeid tussen Jood en heiden ophef, 'n heiden hoef nie Jood te word nie. Paulus wil met sy skrywe die Christene in Rome los van die sinagoge in 'n gemeente organi- 
seer en hulle so vir SY universele evangelie, vry van die wet, wen ${ }^{142}$. As 'n volgende voorbeeld dien Schmithals se opsomming van die omstandighede waaronder Matteus aan sy kerk skryf: "Die Gemeinden leben unter - örtlich sicherlich unterschiedlich starken - Verfolgungen und Bedrängnissen, die vor allem van der Synagoge ausgehen $^{\prime 143}$. Matteus bedoel om 'n OPENBARE onderwysing aan die GEMEENTE te gee. Christene word aangespreek en nie heidene nie. Hierdie evangelie veronderstel die Christelike geloofsverkondiging sonder om dit self te bevat. Veral vrae in verband met etiek, gemeente-orde, persoonlike vroomheid en eskatologie word vir reeds gedoopte lidmate behandel ${ }^{144}$. So ' $n$ hipotese oor die omstandigheid van 'n geskrif moet natuurlik voortdurend aan die teks self getoets word, al is dit aanvanklik uit die teks gehaal.

Begrip sonder betrokkenheid by die saak wat begryp word is nie moontlik nie. Begrip geskied altyd eietyds, nou. Ek kan nie "in die geskiedenis" begryp nie. Ek kan ook nie 'n afgehandelde saak "as sodanig" verstaan nie. Begrip kom nie nadat twee afsonderlike stappe geneem is nie: die verstaan van die verlede en dan die oordra daarvan op die huidige werklikheid. As ek die Bybelse tradisie van Christus vandag wil verstaan, is ek self en die huidige situasie reeds van die begin af deel van hierdie proses. As ek werklik onder die huidige omstandighede verstaan, verstaan ek die Bybelse Tradisie "as sodanig".

Uit hierdie samehang en wisselwerking bestaan die hermeneutiese sirkel. Die eksegeet gebruik die histories-kritiese metode dus van die begin af met ' $n$ bepaalde perspektief en hierdie perspektief is die oortuiging dat daar in hierdie tekste fundamentele uitsprake oor die menslike bestaan gemaak word. Schmithals is oortuig dat "der biblische Text nur im Vollzug der Existenz, also, EIGENTLICH, recht verstanden wird; dass er nur da WESENTLICH ausgelegt wird, wo ich mich von ihm auslegen lasse; dass ich ihn nur da verstehe, wo ich mich selbst in ihm neu verstehe"145.

Die bedoeling van die histories-kritiese metode is om die AANSPRAAK wat die teks maak, te hoor. Hierdie aanspraak, byvoorbeeld dat Jesus opgestaan het, kon op geen manier histories ondersteun word nie, ewe min kan dit met historiese bewyse ondergrawe word, dit kon net in geloof aanvaar of in ongeloof verwerp word. Die teks is nie bedoel as begronding vir die geloof nie, maar as uitdrukking daarvan ${ }^{146}$. Die histories-kritiese eksegese wil die BOODSKAP wat die teks oorbring, hoor en opnuut vir vandag onder woorde 
bring. 'n Toepassing van hierdie insigte kry ons byvoorbeeld wanneer 'n prediker die paasboodskap verkondig in plaas van om oor die geloofwaardigheid van die paasgebeure te praat.

Omdat die histories-kritiese eksegeet die hermeneutiese sirkel voltooi en probeer om "das biblische Christuszeugnis hier und jetzt zu VERSTEHEN, ist er sein eigener Dogmatiker"147. Dit is dus nie waar dat die eksegeet die materiaal verskaf waarmee die dogmatikus die gebou van die teologie bou nie. Van werklike arbeidsverdeling tussen eksegeet en dogmatikus is daar geen sprake nie. Menige student moes al onverrigter sake tussen eksegese en dogmatiek rondskarrel soos van Pontius na Pilatus. In werklikheid moet ons 'n keuse maak "jeder muss sehen, ob er besser auf diesem oder auf jenem methodischen Weg zum Theologen werden kann"148.

Juis die eie dogmatiek - die eksistensiale interpretasie - van die, histories-kritiese benadering, soos deur Bultmann en Schmithals verteenwoordig, gee aanleiding tot die beskuldigings dat dit neerkom op ' $n$ individualistiese vereniging, subjektiewe selftevredenheid, innerlikheid, abstraksie van die werklikheid. Schmithals antwoord dat die wêreld, die naaste, die gemeenskap, die toekoms, die gewete, die verlede, die dood deel van menswees, d.i. die menslike eksistensie is. "Personale Existenz IST soziale Existenz, 'Dasein' ist immer, in der Welt da sein"'149. Om die mens te verstaan beteken tegelyk die wêreld en die geskiedenis, die naaste en die gemeenskap, die natuur en kultuur as die werklikhede te verstaan waarin ons menswees afspeel. "Jesus Christus verstehen heisst, das menschliche Dasein mit der es umgreifenden Wirklichkeit der Welt aus seinem ständigen göttlichen Ursprung verstehen"150.

Die voorafgaande aanhaling noem ons 'n eksistensiale uitspraak. Dit is ' $n$ algemene uitspraak oor die wese van die menslike bestaan. Daarmee is nog geen besluit geneem nie. Die oomblik as iemand homself met die omvattende werklikheid van die wêreld wat hom omring uit sy voortdurende goddelike oorsprong verstaan, verstaan hy Jesus Christus EKSISTENSIEEL. In die eksistensiale analise het ons dus met ' $n$ bewuste objektivering te doene, wat telkens in die eksistensiële toe-eiening oorbrug word ${ }^{151}$. In 'n eksistensiale analise sou ons kan sê wat geloof is, maar geloof self geskied altyd persoonlik, eksistensieel. Ons kan verder onthou dat soos wat die hermeneutiese beginsel - die eksistensiale interpretasie - die historiese metode afrond, sorg die historiese metode, die bly-by-die-teks, weer op sy beurt dat die eksistensiale interpretasie nie subjektivistiese 
willekeur word nie. As iemand ' $n$ beter hermeneutiese beginsel en 'n beter metode het, moet hy dit "um Gottes willen anwenden" 152!

\section{PAULUS EN DIE GNOSTIEK}

Die Gnostiek is 'n godsdienstige beweging wat volgens Schmithals aan die begin van die derde eeu vC met die ontmoeting van die Griekse en Oosterse gedagtewêrelde in Mesopotamië ontstaan het ${ }^{153}$.

Hierdie beweging verkondig 'n kosmiese dualisme, waarvolgens God en die Skepper van die wêreld onderskei moet word en hiermee saam 'n antropologiese dualisme, waarvolgens die menslike siel, wat deel van die goddelike substansie is, in die kerker van sy liggaam deur die demoniese heersers van die wêreld gevange gehou word, maar die verlossing is seker omdat die mens kennis dra van sy goddelike oorsprong ${ }^{154}$.

Van die materiaal wat tot beskikking van die Gnostiek was, is die sogenaamde Oermens-mite. Hiervolgens is die siele van individuele mense deeltjies van een hemelse gestalte, die Oermens, wat deur godvyandige magte oorweldig, verskeur en in individuele stoflike liggame gevang is, nadat die herinnering aan hul hemelse oorsprong uitgedoof is ${ }^{155}$. Die bydrae van die Gnostiek lê daarin dat die mens weer van sy goddelike oorsprong bewus word ${ }^{156}$.

In 1 Korintiërs 12:27 staan: "Julle is die liggaam van Christus en afsonderlik is elkeen 'n lid daarvan." Schmithals sien die verrassende van hierdie formulering in die feit dat Paulus Christus skryf maar tog die kerk bedoel. Dit beteken die kerk word met Christus geïdentifiseer en elke lidmaat is 'n deel van die liggaam van Christus ${ }^{157}$. Om dit te verklaar stel Schmithals as hipotese dat daar reeds voor Christus 'n Christus-Messiasgnostiek ontwikkel het waarin die Oermens met Christus geïdentifiseer is ${ }^{158}$. Hierdie Christus het met die kerklike Christus niks te doene nie, maar val binne 'n Joodse Gnostiek ${ }^{159}$.

Op die beswaar dat daar geen direkte literêre getuienis van so 'n Joodse Gnostiek bestaan nie antwoord Schmithals dat die uitbreiding van die kerk in Sirië 'n einde aan so 'n literatuur gemaak het en verder dat 'n Gnostiek wat die goddelike vonk, die Christus in elke mens wil wakker maak nie behoefte aan 'n openbaringsliteratuur het nie. Die letter sal net doodmaak ${ }^{\mathbf{1 6 0}}$.

In sy proefskrif "Die Gnosis in Korinth" probeer Schmithals om aan die hand van die Korintiërbriewe die teologie van Paulus se 
Gnostiese teenstanders in Korinte vas te stel. Schmithals begin met 'n ondersoek na 1 Korintiërs 12:1-3 waarin staan: "Vervloek is Jesus"161. Die gemeente is onseker daaroor of iemand so iets "deur die Gees van God" kan sê en vra Paulus vir meer duidelikheid. Schmithals meen dat die "vervloek" dit waarskynlik maak dat dit Jode kan wees, die waarvan Paulus in 2 Korintiërs 11:22 sê: "Is hulle Hebreërs? Ek ook." Hulle gaan deur as Christene, hulle bely Christus, maar ontken dat hy uit 'n vrou gebore is, dat hy Jesus kan wees en in ekstase roep hulle: "Vervloek is Jesus"162!

Met behulp van sy Gnostiese hipotese kan Schmithals ook die probleem van die swye van die vrou in die gemeente opklaar. Anders as in 1 Korintiërs 11:2 e.vv. verbied Paulus in 1 Korintiërs $14: 33 \mathrm{~b}-36$ vroue om in die gemeente die woord te voer. Schmithals skryf hierdie twee gedeeltes aan twee afsonderlike briewe van Paulus toe. Paulus het eers geen beswaar gehad nie, maar later die Gnostiese agitasie daaragter ontdek. Volgens die Gnotici was dit absurd om op grond van liggaamlike verskille onderskeid tussen man en vrou te maak. Al wat saak maak is die goddelike vonk. Teen hierdie agtergrond wil Paulus hierdie vryheid nou inperk ${ }^{163}$.

Schmithals is oortuig dat "gnosis" die sentrale teologiese begrip by Paulus se teenstanders was ${ }^{164}$. Hierdie kennis bevry die mens uit sy toestand van onwetenheid en lei hom tot kennis van homself, van God en van die demone. Hierdie kennis waarborg ook die onsterflikheid. Die mens is immer kragtens sy oorsprong goddelik ${ }^{165}$. Teen hierdie selfgenoegsame kennis polemiseer Paulus met die "woord van die kruis", wat as eskatologiese Woord van God in oordeel en genade die hoogste uitdrukkings van God se wil is. Net so stel Paulus geloof, hoop en liefde teenoor die "gnosis"166.

Ten spyte van die hedendaagse tendens om elke brief of selfs perikoop geïsoleerd te ondersoek gaan Schmithals van die standpunt uit dat Paulus oor ' $n$ wye terrein met sy derde sendingreis, met dieselfde Gnostiese teenstanders te doene gehad het ${ }^{167}$. Schmithals kry spore van hierdie stryd behalwe in 1 en 2 Korintiërs ook in Romeine 16, Galasiërs, Filippense, 1 en 2 Tessalonisense ${ }^{\mathbf{1 6 8}}$.

Hierdie teorie van Schmithals is sedert hy dit geloods het, druk onder bespreking. Tot nou toe is Schmithals nog nie oortuig dat iemand anders 'n beter verklaring aanbied nie ${ }^{169}$.

Schmithals beskou Paulus nie as die skepper van die kerklike tradisie waarin die gnostiese uitdrukkingswyse voorkom nie, byvoorbeeld "ons in Christus" en "Christus in ons". Paulus is wel die 
oudste getuie daarvan. Dit kom ook by die Deuteropauliniste, veral in Efesiërs en Kolossense voor ${ }^{170}$. Schmithals meen dat ons nie verkeerd is as ons die oorsprong van hierdie tradisie by Stafanus en die Kring van Sewe soek nie ${ }^{171}$.

\section{APOSTELAMP}

Ook die kerklike apostelamp is volgens Schmithals van Gnostiese oorsprong. "Die ursprüngliche Konzeption des Apostolats ist gnostisch" 172 . Schmithals voer verskeie argumente aan om hierdie stelling te boekstaaf. Een argument lui dat die Oer-gemeente in Jerusalem nie uit hul eie tot 'n georganiseerde sending sou kom nie. Hulle het op die aanbreek van God se heerskappy in Jerusalem gewag, wat nie meer lank sou neem nie. Die Gnostiek het nie meer gewag op die eskatologiese ingrype van God nie. Volgens hulle het God sy laaste daad reeds gedoen: die verlossende gnosis is gestuur. Die mense het nou self die taak om die voleinding af te dwing, waarin al die verstooide ligvonke deur die gnosis versamel en weer in die kosmiese liggaam van Christus ingevoeg word. Die enkele gnostikus is eers dan verlos as die liggaam van Christus herstel is. "So entstanden mit der Gnosis zwangsläufig gnostische Mission und gnostischer Apostolat, und beides wurde von den kirchlichen Kreisen in syrischen Raum übernommen ${ }^{\prime 173}$.

So 'n gnostiese apostel kon te eniger tyd deur ekstase, spreek in tale en ontrukkinge die geldigheid van sy boodskap en amp bewys. In Korinte is Paulus uitgedaag om homself so te bewys. In 2 Korintiërs 12:1-2 skryf hy: "Om te roem het wel geen sin nie, maar terwyl dit dan nou moet, kom ek by gesigte en openbarings wat die Here gegee het. Ek ken 'n man 'en Christōi'. Veertien jaar gelede is hy weggeruk tot in die derde hemel. Of dit nou met die liggaam was of sonder die liggaam, weet ek nie, net God weet dit."

Vir Schmithals is dit duidelik dat Paulus in hierdie gedeelte bitter is oor die feit dat hy nie oor Christus nie maar oor homself moet roem. Die "gesigte en openbarings" is die hoogste vorm van ekstase, want die gnostikus se siel verlaat sy liggaam en duik in in die kosmiese liggaam van Christus. So 'n siening veronderstel 'n streng dualisme van siel en liggaam. Schmithals ontken dat Paulus hier aan so 'n gnostiese hemelreis deelneem, want Paulus aanvaar nie so 'n dualisme nie. ' $n$ Verdere bewys hiervoor is dat Paulus twee maal beklemtoon dat hy nie weet of dit met die liggaam of sonder die 
liggaam was nie. Vir' 'n gnostikus is so 'n stelling ondenkbaar. Dit gaan vir Paulus daarom dat hy in een oomblik van sy aardse lewe die hemelse doel bereik het, dat sy geloof 'n aanskoue geword het. Hiermee neem Paulus stelling in teen sy teenstanders wat reeds die versadiging smaak, wat deur hul ekstase bewys lewer van die heil wat hulle besit. Ten spyte van sy geloofsvertroue bly Paulus bewus van die "nog nie". Die "man in Christus" is Paulus soos wat hy sal wees en veertien jaar gelede in 'n verbygaande oomblik was ${ }^{174}$.

\section{PASTORALE BRIEWE}

Schmithals vind in die Pastorale Briewe, 1 Timoteus, 2 Timoteus, Titus, 'n direkte polemiek teen 'n Gnostiek met Joodse karakter. Teenoor die entoesiasme van die Gnostiek stel die kerk die REGTE LEER. Hierdie leer kom van Paulus wat dit aan Timoteus en Titus oorgelewer het. Teen die Gnostiese geesdrywers stel die kerk die geordende ampsdraer. Verder tref die kerk ook bepaalde reëlings in verband met die erediens, die huis en die huwelik om die Gnostiese entoesiasme af te weer ${ }^{173}$.

\section{DIE HELLENISTIESE GEMEENTES EN DIE JOODS- CHRISTELIKE OER-GEMEENTE IN JERUSALEM}

Schmithals verstaan Galasiërs 2:1 e.vv. nie as 'n berig oor die erkenning wat Paulus van die ander apostels sou ontvang nie. Paulus het nie sy evangelie "aan die broers daar voorgelê" nie, maar hulle vertroud gemaak met die evangelie wat hy lankal onder heidene verkondig ${ }^{176}$. Die rede hoekom Paulus dit doen is om die ooreenkoms te bereik waarvolgens hy aan die nie-Jode sy evangelie, vry van die wet, sal verkondig en die ander aan die Jode die evangelie met wetsonderhouding ${ }^{177}$.

Die grond vir hierdie etnografiese werksverdeling vind Schmithals in die praktiese oorweging dat dit vir die JODE-Christene in Juda lewensgevaarlik was om heeltemal van die wet los te breek. Die Jodedom kon nog 'n laksheid in wetsonderhouding verdra, maar wanneer die wet met alles waarvoor dit staan grondig bevraagteken word, kry sulke mense met die nasionale weerstand van die Jodedom te doene, soos Stefanus byvoorbeeld ${ }^{178}$.

Die ooreenkoms tussen Paulus en die ander lui die begin van Paulus se selfstandige sendingarbeid in Kleinasië en Griekeland in. 
Paulus stig hier die eerste gemeentes wat uit heiden-Christene bestaan $^{179}$. Paulus sou nie met sy evangelie dat Christus die einde van die wet is maklik by die sinagoge kon aanknoop nie ${ }^{180}$. Die heidense Godvresendes was sy uitgesoekte gehoor ${ }^{181}$. Maar Paulus sou ook nie sy "broeders na die vlees" in die steek laat nie, daarom verwag hy van die ander om wanneer hy onder heidene werk dat hulle onder die Jode besig sal wees ${ }^{\mathbf{1 8 2}}$. So kon Paulus en Petrus maklik saam in Rome die evangelie verkondig, die een 'n Jood vir die Jode en die ander ' $n$ heiden vir heidene ${ }^{183}$.

\section{LUKAS}

Schmithals is van mening dat die Evangelie volgens Lukas en die Handelinge van die Apostels saam gelees en beoordeel behoort te word $^{184}$. So gedoen, meen Schmithals dat Lukas deurgaans deur dieselfde temas gelei word. Ons belangstelling is hoofsaaklik hierop toegespits. Lukas rig sy skrywe teen 'n premarcionitiese kettery ${ }^{185}$. Lukas hou die kerk voor as een van hart en sin, maar na die dood van Paulus het die "wrede wolwe" onder die kudde ingedring. Die wolwe kom uit eie geledere ${ }^{186}$. Dit is nie seker of hierdie kettery ontstaan het uit 'n poging om hulself van die vervolgde Jodedom te distansieer nie en of die radikale Paulinisme in reaksie teen die oppervlakkige gemeenteteologie, soos dit in die Lukas-evangelie weerspieël word, gekom het nie. Daar het in elk geval 'n kerklike rigting ontstaan "die sich unter ausschliesslicher Berufung auf Paulus und seine Gesetzeskritik gänzlich vom jüdischen Mutterboden der Kirche löste und auch das Alte Testament verwarf"187.

Om hierdie Paulinisme te bestry teken Lukas ' $n$ ander beeld van Paulus as wat hy self aanbied en waaraan die ketters vashou. Anders as die twaalf apostels het Paulus die opgestane Heer nie gesien nie en ook nie saam met Hom geëet en gedrink nie. Op pad na Damaskus is Paulus deur die lig verblind sodat hy van luister afhanklik is. Hoewel Paulus self sê dat hy "die Here gesien" het, is dit volgens Lukas 'n ander "sien" as die van die apostels. Lukas noem Paulus ook nêrens "apostel" nie ${ }^{188}$. Schmithals meen dat Lukas Paulus nie wil degradeer nie, maar onder die Apostoliese Tradisie wil inbring ${ }^{189}$. Net die twaalf is gesaghebbende draers van die tradisie omdat hulle van die begin af ooggetuies en dienaars van die Woord was" $^{\prime 190}$. Toe Jesus nog geleef het, het die twaalf al gepreek en gesond gemaak $^{191}$. Anders as Markus wat die ongeloof in Jesus se binnekring 
duidelik skilder, vermy Lukas sulke opmerkings. Hy laat Petrus byvoorbeeld nie sweer dat hy met Jesus niks te doene het nie. Schmithals stel dit so: "Vielleicht will Lukas gar sagen: Petrus leugnet nur deshalb, Jesus zu kennen, weil er in seiner Nähe ausharren möchte" ${ }^{\prime 192}$.

Schmithals lees ook Lukas se weergawe van Jesus se hemelvaart in die lig van die stryd teen die Hiperpaulinisme. Jesus verkeer na sy opstanding liggaamlik by die twaalf apostels. Dan verlaat $\mathrm{Hy}$ hulle en die aarde om eers weer aan die einde van die tyd terug te kom. Dit wil sê die twaalf word in 'n onaantasbare uitsonderlike posisie geplaas ${ }^{193}$. Vir die tyd waarin $\mathrm{Hy}$ afwesig sal wees stuur Jesus die Heilige Gees om Hom te "vervang"194. Deur die krag van die Heilige Gees sit die twaalf Jesus se werk voort deur woord en daad. Hiermee word die kerk gebou en alle ander hemelse openbaringe word uitgesluit, selfs die van Paulus ${ }^{195}$.

Lukas stel Jesus as 'n vroom Jood voor wat gewoond was om op die sabbatdag sinagoge toe te gaan. Jesus begin sy openbare werksaamheid deur in die sinagoge te leer. Lukas wil met hierdie opmerking beklemtoon dat Jesus in die Joodse volk, wat instemmend na Hom luister, veranker is en dat kerk en Israel onlosmaaklik aan mekaar verbind is ${ }^{196}$. Lukas laat self vir Paulus ook in die sinagoges optree hoewel dit nie histories korrek kan wees nie, omdat Paulus deur die sinagoge vervolg is en hy met die ander apostels ooreengekom het dat hy na die heidene en hulle na die Jode sal gaan. Lukas wil so "dem Leser den bleibenden Ursprung des heidenchristlichen Evangeliums in der Heilsgeschichte Israels einschärfen, den das Alte Testament verwerfenden Irrlehrern zum Trotz ${ }^{\prime 197}$. Volgens Schmithals het Lukas nie grondig nagedink oor die kontinuïteit tussen kerk en Israel nie, hy staan eenvoudig net daarby dat die Ou Testament belangrik bly ${ }^{198}$. In wat met Jesus gebeur word die Skrif vervul. Die ware Israel word nie deur die kerk opsygeskuif of weerlê, soos die ketters dink nie, maar in die Christelike gemeente opgeneem ${ }^{199}$. Die Christendom is die universeel-uitgebreide Jodedom. "Der EINE Gott, das Angebot der Busse und Vergebung, die Predigt des Gerichts und der leiblichen Auferstehung sind die Hauptinhalte der jüdischen wie der christlichen Predigt ${ }^{\prime 200}$.

Schmithals is oortuig dat Lukas nie werklik 'n teologie van die kruis ontvou nie ${ }^{201}$. Lukas laat Jesus 'n profetedood sterf: "Jerusalem, Jerusalem! Jy wat die profete doodmaak en die boodskappers stenig wat na jou gestuur is" (Luk 13:34). Jesus sterf die dood van 'n Joodse 
martelaar ${ }^{202}$. Jesus sê vir die misdadiger aan die kruis: “Vandag sal jy saam met My in die paradys wees." Die gedagte dat die belyer dadelik in hemelse heerlikheid opgeneem word, kom uit die Jodedom wat tydens die Makkabeërtyd 'n martelaarsteologie ontwikkel het $^{203}$. Ook Petrus het in sy toespraak op pinksterdag geen kruisteologie voorgedra nie. Schmithals meen dat Lukas met opset die soenofferteologie waarmee sy teenstanders die eenheid van die kerk bedreig, vermy ${ }^{204}$. Volgens Lukas is die mens ook nie totaal aan die sonde verval soos vir Paulus nie. Die mens het die moontlikheid om die Satan, wat bloot versoeker is en nie "heerser van hierdie wêreld" nie, te weerstaan. Sonde is vir Lukas nie die mens se selfhandhawing voor God nie, maar oortreding van goddelike gebooie. "Vergewing van sondes" is in God se mag en het nie die kruisgebeure nodig nie $\mathrm{e}^{205}$.

'n Ander manier waarop Lukas die kontinuiteit tussen kerk en Israel bewaar, is dat die kerk hoofsaaklik deur die Joodse leiers vervolg word, terwyl die volk wat die ware Jodedom verteenwoordig "christenfreundlich" is ${ }^{206}$. Onder leiding van die Fariseërs het die sinagoge na die Joodse opstand hulself van die (heiden-)Christelike kerk gedistansieer. Lukas se teenstanders gebruik hierdie feit om die kerk van sy Ou-Testamentiese bodem los te maak, maar Lukas vertel dat die Ou Testament en Jesus hierdie ontwikkeling sien kom het: "En daar was baie melaatses in Israel in die tyd van die profeet Elisa. Tog is nie een van hulle genees nie, maar wel Naäman, die Siriër" (Luk 4:27). Die Jode moet self die skuld vir hierdie toedrag van sake dra; dit was nie Jesus of die Oer-gemeente se bedoeling nie ${ }^{207}$.

Lukas hou Jesus as voorbeeld aan die martelare van die kerk vir wie hy skryf voor. Lukas beskryf die situasie van 'n martelaar voor die laaste belydenis: "'n Engel uit die hemel het aan Hom verskyn en Hom versterk. Hy het in doodsangs geraak en nog ernstiger gebid. Sy sweet het soos bloeddruppels geword wat op die grond val" (Luk 22:43 e.v.). "In eben dieser Situation der Versuchung soll der Märtyrer in der Nachfolge Jesu Zuflucht beim inständigen Gebet suchen" ${ }^{208}$. Lukas is die "evangelis van gebed" want "die verfolgte Gemeinde hat keine andere Kraft und Macht" ${ }^{\prime 209}$.

Schmithals verklaar Lukas se armoedsvroomheid ook uit die situasie van vervolging. Die Romeinse owerheid het die kerk as deel van die opstandige Jodedom rondom die Joodse opstand van 66-70 beskou en vergesogte politieke verwyte teen die kerk gemaak ${ }^{210}$. Die normale straf vir 'n gelowige was dat sy aardse besittings gekonfis- 
keer is. Onder hierdie omstandighede vertel Lukas van Levi wat "alles verlaat" het en Jesus nagevolg het, maar tog "'n groot feesmaal" vir Jesus, baie tollenaars en ander gaste gegee het. Met sy liefdesmaaltyd word Levi 'n voorbeeld van die gelowige wat nog in besit van sy aardse goed is en dit met ander wat dit verloor het, deel. "Alles verlaat" beteken om jou besittings nie vir jouself te hou nie maar die ander 'n aandeel daaraan te gee $^{211}$. Lukas beskryf dit wat in die gemeente behoort te geld asof dit so is. Lukas as "evangelis van die armes" moet uit die destydse omstandighede verstaan word en nie uit ' $n$ armoedbeheptheid of as kommunisties of omdat besit skadelik vir die siel is nie. "Der zum Bettler gewordene Bekenner sollte mit der Solidarität derer rechnen können, die ihren Besitz noch behalten haben"212.

Schmithals herken ook 'n politieke apologie wat Lukas namens die vervolgde kerk van sy tyd aanteken. Pilatus sê herhaaldelik dat hy in Jesus geen skuld kry nie. Pilatus laat Jesus onder massiewe druk van die Joodse leiers kruisig ${ }^{213}$. Herodes gaan self so ver om Jesus met 'n koninklike kleed te bespot, duidelik oortuig van hoe ongevaarlik Jesus vir hom is. Pilatus en Herodus is so eens dat Jesus onskuldig is, dat hulle weer vriende word ${ }^{214}$. As Pilatus en Herodus so oor Jesus geoordeel het, verdien die kerk 'n beter behandeling van die owerheid. Dis nie die Christene wat politieke oproer aanblaas nie, maar die Joodse leiers, daarom wil hulle Barabbas op vrye voet hê ${ }^{215}$. Lukas hou hierdie apologie vol tot by die laaste woord in Handelinge: "ongehinderd".

Paulus, wat hom as lojale staatsburger op die keiser beroep, verkondig ongehinderd die evangelie onder keiserlike bewaking. Lukas vertel dit ten spyte van die feit dat Paulus die marteldood in Rome gesterf het. Hiermee wil Lukas sê hoe die owerheid van sy tyd teenoor die kerk behoort op te tree ${ }^{216}$. Voor Feliks sê Paulus: "Ek staan vandag hier voor julle tereg omdat ek aan die opstanding van die dooies glo." Schmithals verklaar "opstanding van die dooies" as "die Hoffnung auf ein jenseitiges Reich Gottes"217.

Schmithals verstaan Lukas, "evangelis van vroue", ook teen die agtergrond van die vervolging. Die vervolging het eerstens sy tol onder die gemeenteleiers geëis, daarna die familiehoofde, sodat die vroue oorgebly het. Veral die finansieel-selfstandige Griekssprekende vroue het die taak gekry om die gemeente te onderhou en vir die wat hul besittings verloor het te sorg. "Lukas ehrt diese Frauen seiner Zeit, indem er ihren Dienst in das Leben Jesu einzeichnet, 
den Frauen in seinen Gemeinden damit zugleich ein Vorbild gebend" ${ }^{\prime 218}$.

Schmithals som Lukas op as 'n standvastige kerkman; sy hoofdoel was om sy gemeentes teen dwaalleer te beskerm en hulle in tyd van vervolging te versterk; hy was 'n geleerde man en uitstekende verteller; as teoloog was hy waarskynlik swakker as sy teenstanders. 'n Swakheid waaraan die eksegeet niks kan doen nie ${ }^{219}$.

\section{MARKUS}

Schmithals onderskei tussen die grondskrif (Grundschrift), die klein versameling Jesus-sêgoed $\left(Q^{1}\right)$ en die redaksionele werk wat Markus aan hierdie twee bronne gedoen het $t^{220}$. In hierdie artikel bepaal ons die aandag by die grondskrif.

Die skrywer van die grondskrif noem Schmithals "Erzähler". Hierdie verteller was nie bloot ' $n$ versamelaar van los mondelinge of skriftelike stukkies in verband met Jesus nie. Die grondskrif is ' $n$ samehangende LITIRERE werk ${ }^{221}$. Moontlik was hierdie verteller die eerste skrywer van 'n "evangelie" waarin die kerklike belydenis in Jesus die Heer verhalend verkondig word ${ }^{222}$. Hierdie verteller verdien om as teoloog in dieselfde asem as Paulus en Johannes genoem te word $^{223}$.

Hoewel Schmithals kan praat van "die Nähe der Grundschrift zur paulinischen Theologie"224, meen hy dat daar geen direkte invloed van Paulus ingewerk het nie. Paulus se regverdigingsleer ontbreek en die Antiogeense aannemingschristologie is anders as die Pauliniese preëksistensiechristologie. Die verteller het hom ook anders as Paulus heeltemal van die apokaliptiese erfenis losgemaak ${ }^{225}$.

Schmithals meen dat die grondskrif kort na die verwoesting van Jerusalem (70) geskryf is. Hierdie gebeurtenis het die godvresende heidene, wat by die sinagoge ingeskakel was, onder die druk geplaas dat hulle van politieke samewerking met die Jode verdink is. Dit het groot getalle Godvresendes na die kerk laat kom. Volgens Schmithals het die verteller sy werk onder hierdie vir die kerk gunstige omstandighede geskryf as "handboek vir die sending" onder die Godvresendes. Die sendelinge is voorafgeleer om hul handboek te verstaan ${ }^{226}$. Schmithals lê die gelykenis van die saaier in hierdie verband uit. Die saad wat op die pad val en deur voëls opgepik word, verteenwoordig die mense wat afwysend op die verkondiging van die kerk reageer, hulle behoort nie aan die ge- 
meente nie. Vir die wat wel aan die gemeente behoort, is daar drie moontlikhede:

1. Die wat pas gekom het, maar nie opgewasse teen die vervolging is nie.

2. Die ander wat wel die uiterlike gevare trotseer maar nie die dinge van die wêreld kan hê asof hulle dit nie het nie.

3. Die beproefde gemeentelede. Volgens Schmithals is die verteller hier besig om die baie "katkisante" duidelik in te lig oor die konsekwensies van kerklike lidmaatskap"227. "Jesus erzählt das Gleichnis, als sich zum erstenmal vor der diffusen Volksmenge eine Gruppe absondert, die im (christlichen) Haus auf nähere Unterweisung begierig ist"228.

Van die opvallendste kenmerke van hierdie Schmithals-kommentaar is die baie aanhalings uit die kerklike gesangboek en hoe Luther telkens gebruik word om 'n saak duideliker te stel. Ek tel nie minder nie as agt en dertig Luther-aanhalings.

Luther het hom graag vir sy Twee-Ryke-Leer op Markus 12:17 beroep: "Jesus sê toe vir hulle: 'Gee aan die keiser wat aan die keiser behoort, en aan God wat aan God behoort.' "

"Das vornehmste Stück in diesem Evangelium ist, dass er uns hier den Unterschied zwischen den beiden Reichen lehrt, die wir das göttliche und weltliche nennen"229. Schmithals lê die verteller so uit dat Jesus die bestaan van die staat met die muntstuk uit die sak van sy vraagstellers op profane wyse begrond ${ }^{230}$. "Jeder metaphysischen Verwurzelung staatlicher Macht wird damit abgesagt ${ }^{\prime 231}$. Hierdie woorde van Jesus is so geformuleer dat dit in stryd is met die apokaliptiese anargie sowel as die teokratiese Zelotisme van daardie tyd. Dis ook teen die keiserkultus en die gedagte dat die owerheid dienaar van God is, soos in die na-Pauliniese teks (Rom 13:1-7) verteenwoordig, gemik ${ }^{232}$. “Der Kaiser regiert nicht, ohne dass Gott ihn regieren lässt." en Schmithals vervolg verder "aber davon, dass der Kaiser ein göttliches Mandat besitze, kann keine Rede sein" ${ }^{233}$. Luther kan hom volgens Schmithals vir sy leer van die twee REGIMENTE van God nie op Markus 12:17 beroep nie, maar wel op Romeine 13:1-7. Luther is ook met hierdie leer nie beskerm teen die misverstand dat die staat 'n metafisiese grootheid is nie. "Näher steht LUTHERS Zwei-REICHE-Lehre unserem Text"234. Die groot kuns is om hierdie twee ryke uitmekaar te hou. Die gelowige leef in die ryk van Christus, die eskatologiese heerskappy van God, uit die 
Woord van genade en vergewing; hy leef terselfdertyd in die werklikheid van die gevalle wêreld, om hier die hoogste mate van welsyn aan mense, reg en geregtigheid uit die krag van geloof en in die vryheid van liefde tot stand te bring. Die beslissing WAT die gelowige sal doen, kan nie deur wette aan hom opgedring word nie. $\mathrm{Na}$ die beste van sy wete - wat stukwerk bly - tree hy in elke situasie "ter wille van die mens" op ${ }^{235}$. Schmithals verstaan Jesus se ongodsdienstige formulering in Markus 3:4: "Mag 'n mens op die sabbatdag goed doen of kwaad doen, iemand red of doodmaak?" as 'n bewuste poging om enige kortsluiting tussen die twee ryke te vermy. "Dieser Massstab erlaubt es dem Christen, sein konkretes Tun als 'humanes' Tun zu verstehen" ${ }^{236}$.

Vir ander eksegete is die genesing van Petrus se skoonmoeder, (Mark 1:29-31), 'n bloot historiese beriggie uit Petrus se herinnering. Schmithals pas dit in in die teologies-deurdagte werk van die verteller en haal dan heelwat uit uit die gedeelte wat binne Jesus se eerste werksdag val. Die verteller laat dit volg op die genesing van die besetene in Kapernaum; die alledaagse volg op die sabbatdaagse; die huis op die sinagoge; die huislike kring op die publieke kring; die siek vrou op die siek man; die gewone griep in die plek van die dramatiese besetenheid. Dit wil sê: Jesus is nie vir die uitsonderlike situasie bedoel nie, maar vir die alledaagse grondsituasie van die mens: "der Mensch schlechthin bedarf der Hilfe Jesu"237. Die mense vertel Hom van haar en maak op sy hulp aanspraak, wat daarop neerkom dat hulle Hom glo. Jesus neem haar hand en "wek haar op", EGEIREIN. Die verteller gebruik hierdie woord ses keer in wonderberigte en vir die sewende keer in die paasgebeure, die opwekking van Jesus. Dit gaan dus nie om die historiese Jesus wat sekere kwale kan genees nie, maar om die gekruisigde en opgestane Seun van God wat heil bring. Die genesing kom dadelik, want God se heil hoef nie eers te ontwikkel nie, dit skenk volkome hulp aan ons. Petrus se skoonmoeder bedien hulle, want die mens wat deur Jesus van sy onheil bevry is, is tot diens bereid.

Schmithals stem saam met die tipering van die Markus-evangelie as 'n lydensgeskiedenis met 'n breedvoerige inleiding, omdat ook die voorafgaande werke van Jesus die bedoeling van sy lyding weergee $^{238}$. Die verteller bedoel ook nie dat sy vertelling die grondslag vir die belydenis moet lê nie. Die belydenis was lankal bekend, geleer en verkondig voordat die grondskrif ontstaan het ${ }^{239}$. Uit die drie- 
deling "gekruisig, gestorwe, en begrawe" gee ons aandag aan die gekruisig. Ook dit is in drie gedeel:

1. die dra van die kruis na Golgota;

2. die kruisiging en gedrag van soldate;

3. die drievoudige bespotting van die gekruisigde.

Uit hierdie drie volg ons die kruis na Golgota. Simon van Sirene was nie voorheen 'n dissipel nie, hy word dit deur Jesus se kruis te dra. "Om Jesus se kruis te dra" beteken vir die verteller "den Akt des Christ-Werdens, des Zum-Glauben-Kommens bzw. das Wesen des Glaubens selbst in der Übernahme des Kreuzes Jesu" ${ }^{240}$. Hierin stem die verteller met Paulus ooreen. Die gelowige word in daardie diepte van die menslike bestaan verneder waar die mens niks meer in sy hand het nie: waar hy God se oordeel oor hom aanvaar en so, aan die dood oorgelewer, slegs op die genade van God hoop, wat die nietige roep dat dit iets sal wees tot sy heerlikheid. "Wer sich mit Jesus so erniedrigt, empfängt in dieser Niedrigkeit die Gnade Gottes; denn in dem gekreuzigten Sohn Gottes ist Gott selbst bei denen, die sich mit Jesus kreuzigen lassen" 241 . Sonder dat Simon dit besef illustreer hy ook wat Jesus se kruis "vir ons" (pro me Jes 53) beteken: ons kom nie deur intellektuele inspanning of deur sosiale diens by die betekenis uit nie, "sondern durch einen existentiellen Akt, in welchem wir Christi Kreuz als das eigene Übernehmen"242. SO versoen die gekruisigde ons met God. Simon word GEDWING om die kruis te dra en die teologie daarvan is: geloof en navolging is nie menslike werk en prestasie nie, maar onverwagte geskenk ${ }^{\mathbf{2 4 3}}$.

Schmithals wys daarop dat kruis en opstanding nie op sigself betekenis het nie, maar slegs met betrekking tot mekaar ${ }^{244}$. Die vroue wat gegaan het om Jesus se liggaam te balsem het nie verwag dat $\mathrm{Hy}$ uit die dood opgestaan het nie. Hy was vir hulle groot in woord en daad en sterf 'n profetedood waarmee Hy sy werk beseël. Hy het die koms van God se ryk aangekondig en die vroue sal weer verder daarop wag dat God sy heilswerk doen en sy ryk oprig. Die kruis is vir hulle einde nie begin nie. Maar in plaas van die dooie Jesus in die graf, sit daar 'n jongman aan die regterkant, die kant wat heil en seën beloof, as God se boodskapper. Voor hierdie goddelike verskyning reageer die vroue met vrees, want in God ontmoet die mens sy regter voor wie hy geen saak het nie. Die engel verkondig dan aan hulle die goddelike "moenie vrees nie". Die nederige ontvang genade. Die plek van die dood word plek van lewe in hierdie eksisten- 
siële sin. Hier in die leë graf word eens en vir altyd aan die mense wat die Heer as vir hulle gekruisig, dit wil sê die gekruisigde as opgestaan erken, gesê: Moenie vrees nie ${ }^{245}$.

Schmithals meen dat die verteller reeds voor sy redakteur Markus 'n "Messiasgeheim" bewaar. Die leser weet sedert Markus 1:11 dat Jesus "Seun van God" is, en Jesus tree ook so op, maar die titel word tydens Jesus se lewe nie bekend gemaak nie. Eers na Pase word Jesus deur die gemeente as "Seun van God" verkondig en "Heer" genoem. "Auf diese Weise kommt der theologische Gedanke zu erzählendem Ausdruck, dass nur der (österliche) Glaube Jesus als den Heiland bekennen kann" ${ }^{\mathbf{2 4 6}}$.

Wat die probleem oor die slot van Markus betref voer Schmithals aan dat Markus 9:2-8a en 3:13-19 in die grondskrif op Markus 16:1-8 gevolg het volgens die belydenis dat Jesus aan Petrus verskyn het, daarna aan die twaalf. Die redakteur Markus verskuif hierdie twee gedeeltes in die lewe van Jesus in en maak van Petrus en die twaalf getuies van die aardse onthulling van Jesus se Messianiteit. Op hierdie manier probeer Markus daardie kringe wat Jesus bloot as profeet vereer, oortuig dat $\mathrm{Hy}$ die Messias is aan die hand van die getuienis van mense wat Hom in lewe gevolg het ${ }^{247}$.

Bibliografie

Schmithals, W 1969. Die Gnosis in Korinth. 3. bearbeitete und ergänzte Auflage. Göttingen: Vandenhoek. FRLANT 66.

Schmithals, W 1961. Das kirchliche Apostelamt. Göttingen: Vandenhoek FRLANT 79.

Schmithals, W 1963. Paulus und Jakobus. Göttingen: Vandenhoek. FRLANT 85.

Schmithals, W 1965. Paulus und die Gnostiker. Hamburg: Reich. Th F 35.

Schmithals, W 1967. Die Theologie Rudolf Bultmanns. 2. Auflage. Tübingen: Mohr.

Schmithals, W c. Beckmann, J 1970. Das Christuszeugnis in der heutigen Gesellschaft. 2. Auflage. Hamburg: Reich. Evangelische Zeitstimmen 53.

Schmithals, W 1970. Wunder und Glaube. Neukirchen: Neukirchner. Biblische Studien 59.

Schmithals, W 1971. Vernunft und Gehorsam. Hamburg: Reich. Evangelische Zeitstimmen 58.

Schmithals, W 1972. Jesus Christus in der Verkündigung der Kirche. Neukirchen: Neukirchener.

Schmithals, W 1973. Die Apokalyptyik Einführung und Deutung. Göttingen: Vandenhoek.

Schmithals, W 1975. Der Römerbrief als historisches Problem. Gütersloh: Mohn. Studien zum Neuen Testament 9.

Schmithals, W c. Gunneweg, AHJ 1978. Leistung. Stuttgart: Kohlhammer. Kohlhammer Taschenbücher 1007.

Schmithals, W 1979. Das Evangelium nach Markus. Gütersloh: Mohn. ÖTK 2/1 u 2/2. Gütersloher Taschenbücher/Siebenstern 503 u 504. 
Schmithals, W c. Gunneweg, AHJ 1980. Herrschaft. Stuttgart: Kohlhammer. Kohlhammer Taschenbücher 1012.

Schmithals, W 1980. Die theologische Anthropologie des Paulus. Stuttgart: Kohlhammer. Kohlhammer Taschenbücher 1021.

Schmithals, W 1980. Das Evangelium nach Lukas. Zürich: Evangelischer. Zürcher Bibelkommentare NT 3.1.

Schmithals, W 1982. Die Apostelgeschichte des Lukas. Zürich: Evangelischer. Zürcher Bibelkommentare NT 3.2 .

\section{Artikels}

Schmithals, W 1961. Pastoralbriefe. RGG V. 3. Auflage. Sp. 144-48

Schmithals, W 1969. Barth, Bultmann und wir. Zum Methodenproblem in der Theologie. Ev. Komm 2 (8), 447-52

Schmithals, W 1970. Theologie und Soziologie. RKZ 111, 166-72, 179-81.

Schmithals, W 1973. Krise und Kritik des Religionsunterrichts. Die Spur 13, 120-27.

Schmithals, W 1973. Die Gegenwart Jesu Christi in seiner Gemeinde. Theologia Viatorum XI. 217-33.

Schmithals; W 1974. Geisterfahrung als Christuserfahrung. Heitmann. C/Mühlen, H (Hrsg.) Erfahrung und Theologie des Heiligen Geistes, 101-17. München: Kösel.

Schmithals, W 1975. Jesus und die Apokalyptik. Jesus Christus in Historie und Theologie, Festschrift Conzelmann, 59-85. Tübingen:Mohr.

Schmithals, W 1976. Christsein ohne Taufe? RKZ 117, 26-28.

Schmithals, W 1976. Utopie und Hoffnung. Berliner Kirchenbriefe 70, 1-11.

Schmithals, W 1977. Noch einmal: Christsein ohne Taufe? RKZ 118, 26-30.

Schmithals, W 1978. Ist die Kirche eine wartende Gemeinde oder eine soziologische Gruppe? RKZ 119, 178-79.

Schmithals, W 1978. Zur Herkunft der gnostischen Elemente in der Sprache des Paulus. Gnosis, Festschrift Jonas, 385-414. Göttingen: Vandenhoek

Schmithals, W 1980. Kritik der Formkritik. Z Th K 77 (2), 149-85.

Schmithals, W 1980. "Kinderabendmahl" in Vergangenheit und Gegenwart. RKZ 121, 153-57.

Schmithals, W 1983. "Ihr sollt dem Bösen nicht widerstreben." Was sagt die Bergpregigt über Gewalt und Gewaltlosigkeit? Evangelische Militärseelsorge 42, 53-72.

Schmithals, W 1983. Judaisten in Galatien? ZNW 74 (1/2), 27-58.

\section{Voetnotas}

1. Agteraan volg 'n volledige bibliografie. In die voetnote volstaan ek met 'n afkorting van die titel, waar nodig, en bladsynommer.

2. Kritik der Formkritik 154

3. Verkündigung $36 \mathrm{e.vv}$.

4. Verkündigung 37

5. Verkündigung 48

6. Verkündigung 49

7. Verkündigung 81 e.v.

8. Verkündigung 83

9. Verkündigung 77 
10. Jesus und die Apokalyptik 67 e.v.

11. Verkündigung 22 e.v.

12. Markus 45

13. Kritik der Formkritik 185

14. Verkündigung 70 e.vv.

15. Die Apokalyptik 32

16. Apokalyptik 28

17. Die Apokalyptik 34

18. Die Apokalyptik 20

19. Die Apokalyptik 119

20. Die Apokalyptik 120

21. Apokalyptik 121

22. Apokalyptik 120

23. Jesus und die Apokalyptik

24. Antropologie 35

25. Krise und Kritik 121

26. Krise und Kritik 121

27. Leistung 106

28. Markus 271 e.v.

29. Anthropologie 44

30. Anthropologie 45

31. Bultmann 313

32. Markus 159

33. Markus 160

34. Anthropologie 58

35. Markus 159

36. Anthropologie 79

37. Markus 159

38. Verkündigung 184

39. Verkündigung 183

40. Verkündigung 185

41. Verkūndigung 183

42. Markus 79

43. Herrschaft 123

44. Markus 522

45. Herrschaft 123

46. Markus 523

47. Markus 522

48. Herrschaft 124

49. Markus 112

50. Gegenwart Jesu Christi 232

51. Anthropologie 92

52. Gegenwart Jesu Christi 230

53. Markus 326

54. Verkündigung 103

55. Verkündigung 110 e.v.

56. Geisterfahrung als Christuserfahrung 117

57. Anthropologie 100

58. Anthropologie 97

59. Gegenwart Jesu Christi 221 e.v.

60. Verkündigung 151

61. Markus 143

62. Markus 94

63. Markus 156 
64. Lukas 67

65. Markus 297

66. Markus 297

67. Leistung 106

68. Markus 419

69. Markus 420

70. Markus 418

71. Anthropologie 103

72. Anthropologie 183

73. Anthropologie 148

74. Verkündigung 110 e.v.

75. Anthropologie 149

76. Anthropologie 115

77. Markus 536

78. Utopie und Hoffnung 1

79. Utopie und Hoffnung 8

80. Utopie und Hoffnung 9

81. Utopie und Hoffnung 9

82. Utopie und Hoffnung 10

83. z B Markus 538

84. Utopie und Hoffnung 11

85. Markus 543

86. Markus 543

87. Markus 196

88. Markus 197

89. Lukas 128

90. Leistung 131

91. Leistung 129

92. Christuszeugnis 36

93. Wunder und Glaube 16

94. Wunder und Glaube 29

95. Wunder und Glaube 17

96. Wunder und Glaube 15

97. Wunder und Glaube 16

98. Wunder und Glaube 26

99. Wunder und Glaube 25

100. Wunder und Glaube 28

101. Wunder und Glaube 97

102. Kirche eine wartende Gemeinde 178

103. Theologie und Soziologie 70 e.v.

104. Markus 742

105. Theologie und Soziologie 167

106. Theologie und Soziologie 171 e.v.

107. Theologie und Soziologie 167

108. Christuszeugnis 23

109. Theologie und Soziologie $\mathbf{1 7 1}$

110. Verkündigung 133

111. Christuszeugnis 42

112. Verkündigung 136

113. Markus 616

114. Gegenwart Jesu Christi 222 e.v.

115. Gegenwart Jesu Christi 231

116. Vernunft und Gehorsam 56

117. Kinderabendmahl 153 
118. Kinderabendmahl 154

119. Kinderabendmahl 155

120. Kinderabendmahl 155

121. Kinderabendmahl 156

122. Kinderabendmahl 156

123. Kinderabendmahl 157

124. Christsein ohne Taufe? 26

125. Christsein ohne Taufe? 26

126. Christsein ohne Taufe? 27

127. Noch einmal 29

128. Noch einmal 29

129. Noch einmal 30

130. Verkündigung 22

131. Verkündigung $\mathbf{1 9 0}$

132. Verkündigung 13

133. Verkündigung 19 e.v.

134. Christuszeugnis 46

135. Bultmann 228

136. Christuszeugnis 45

137. Herrschaft 149 e.vv.

138. Bultmann 249

139. Christuszeugnis 53

140. Barth, Bultmann und wir 447 e.vv.

141. Christuszeugnis 52

142. Der Römerbrief 84 e.vv.

143. "Ihr sollt dem Bösen nicht widerstreben" 58

144. "Ihr sollt dem Bösen nicht widerstreben" 57 e.v.

145. Zeugnis 53

146. Markus 681

147. Barth, Bultmann und wir 449

148. Barth, Bultmann und wir 451

149. Christuszeugnis 54

150. Verkündigung 189

151. Bultmann 70

152. Christuszeugnis 54

153. Gnosis 280

154. Gnosis 26

155. Gnosis 27 e.v.

156. Gnosis 29

157. Gnosis 61

158. Gnosis 69

159. Gnosis 46

160. Gnosis 74

161. Gnosis 117 e.v.

162. Gnosis 120

163. Gnosis 230 e.vv.

164. Gnosis 142

165. Gnosis 141

166. Gnosis 137 e.v.

167. Gnostiker 176

168. Vgl Gnostiker

169. Vgl Judaisten in Galatien?

170. Gnosis 65

171. Zur Herkunft 408 e.vv. 
172. Kirschliches Apostelamt 216

173. Kirschliches Apostelamt 188

174. Gnosis 197 e.vv.

175. Pastoralbriefe Sp. 145 e.v.

176. Paulus und Jakobus 33

177. Paulus und Jakobus 35

178. Paulus und Jakobus 35

179. Paulus und Jakobus 42

180. Paulus und Jakobus 48

181. Paulus und Jakobus 50

182. Paulus und Jakobus 43

183. Paulus und Jakobus 44

184. Lukas 9

185. Lukas 15

186. Apostelgeschichte 189

187. Lukas 14

188. Apostelgeschichte 90

189. Apostelgeschichte 91

190. Lukas 17

191. Lukas 108

192. Lukas 217

193. Lukas 238

194. Apostelgeschichte 24

195. Apostelgeschichte 28

196. Lukas 61

197. Apostelgeschichte 126

198. Apostelgeschichte 46

199. Lukas 183

200. Lukas 11

201. Lukas 12

202. Lukas 157

203. Lukas 226

204. Lukas 211

205. Apostelgeschichte 36

206. Apostelgeschichte 77

207. Lukas 63

208. Lukas 215

209. Apostelgeschichte 51

210. Lukas 13

211. Lukas 72

212. Apostelgeschichte 39

213. Lukas 220

214. Lukas 221

215. Lukas 223

216. Apostelgeschichte 241

217. Apostelgeschichte 214

218. Lukas 101

219. Apostelgeschichte 18

220. Markus 58

221. Markus 44

222. Markus 728

223. Markus 44

224. Markus 48

225. Markus 48 
226. Markus 46

227. Markus 236 e.v.

228. Markus 237

229. Markus 530

230. Markus 528

231. Markus 529

232. Markus 529

233. Markus 530

234. Markus 530

235. Markus 189

236. Markus 197

237. Markus 127

238. Markus 47

239. Markus 681

240. Markus 686

241. Markus 686

242. Markus 687

243. Markus 687

244. Markus 707

245. Markus 710 e.v.

246. Markus 479

247. Markus 715 e.vv. 